\title{
Surficial Geologic Map of the Cuddeback Lake 30' x 60' Quadrangle, San Bernardino and Kern Counties, California
}

By Lee Amoroso and David M. Miller

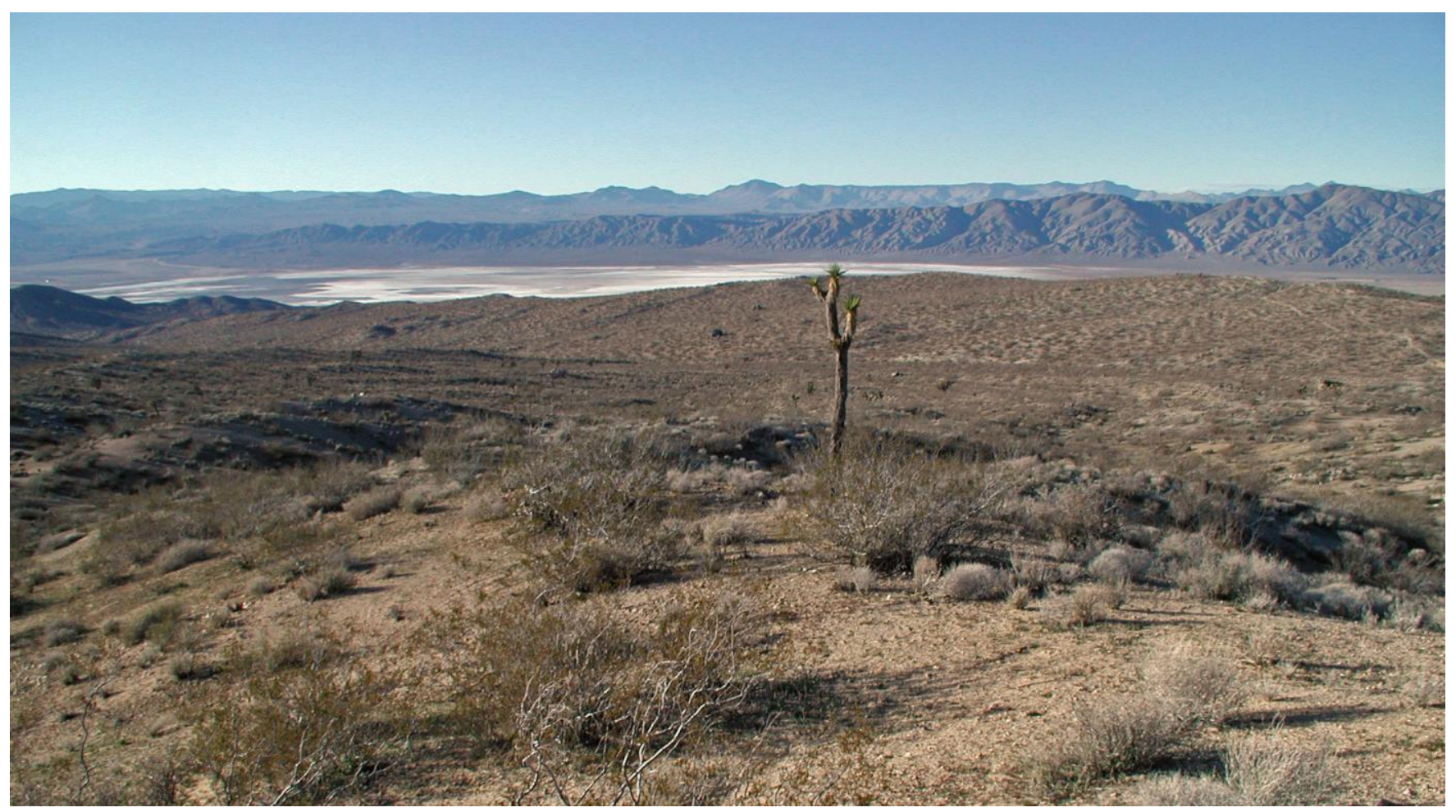

View northwest from the Rand Mountains, of Koehn (dry) Lake, the El Paso Mountains, and the southern Sierra Nevada.

Pamphlet to accompany

Scientific Investigations Map 3107 


\title{
U.S. Department of the Interior \\ KEN SALAZAR, Secretary
}

\author{
U.S. Geological Survey \\ Marcia K. McNutt, Director
}

U.S. Geological Survey, Reston, Virginia: 2012

For product and ordering information:

World Wide Web: http://www.usgs.gov/pubprod

Telephone: 1-888-ASK-USGS

For more information on the USGS-the Federal source for science about the Earth, its natural and living resources, natural hazards, and the environment:

World Wide Web: http://www.usgs.gov

Telephone: 1-888-ASK-USGS

Any use of trade, product, or firm names is for descriptive purposes only and does not imply endorsement by the U.S. Government.

Although this report is in the public domain, permission must be secured from the individual copyright owners to reproduce any copyrighted material contained within this report. 


\section{Contents}

Abstract

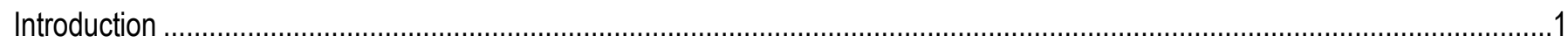

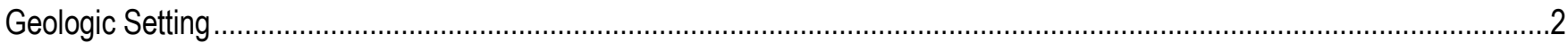

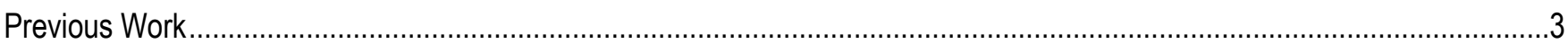

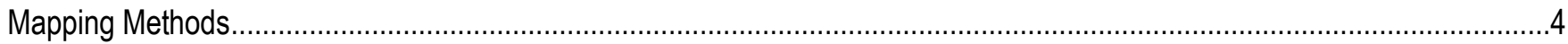

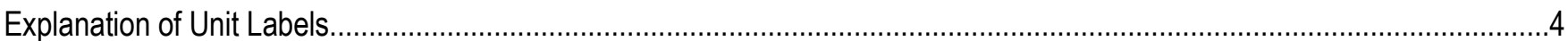

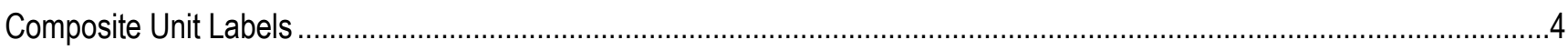

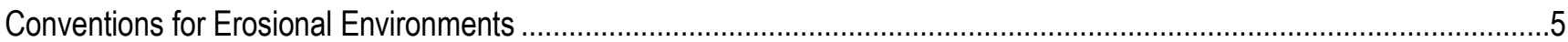

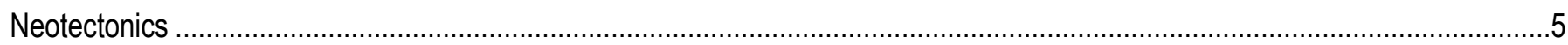

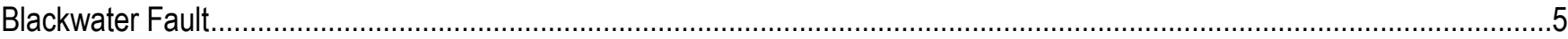

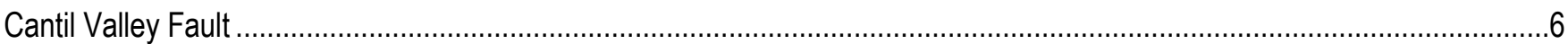

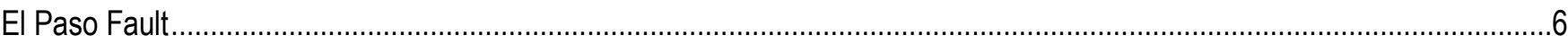

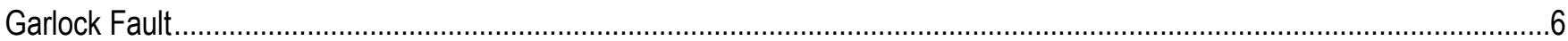

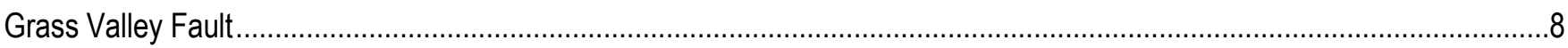

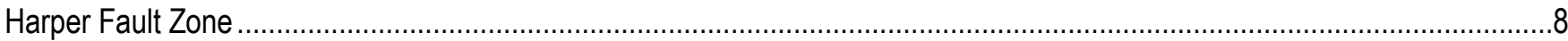

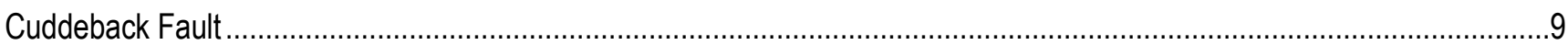

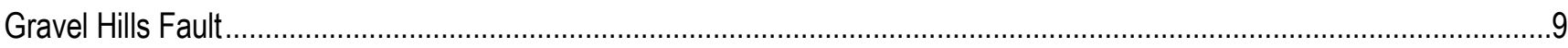

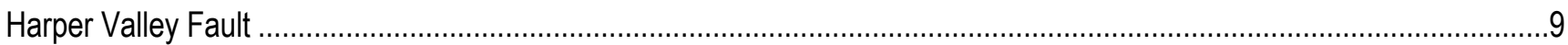

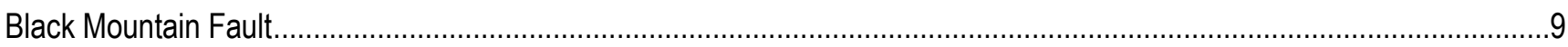

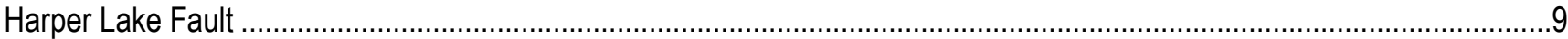

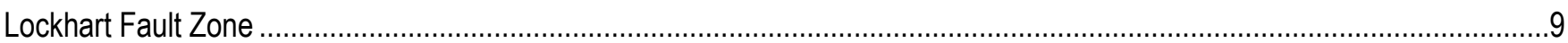

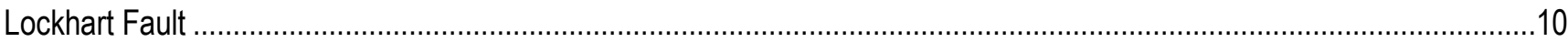

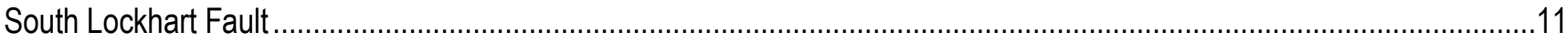

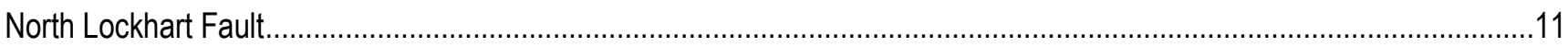

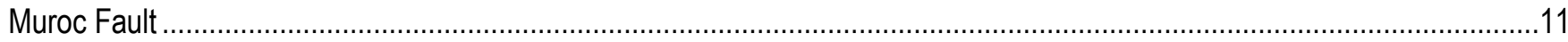

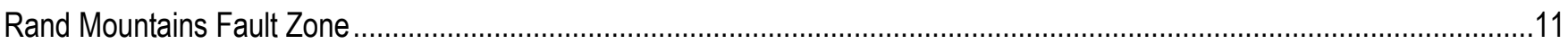

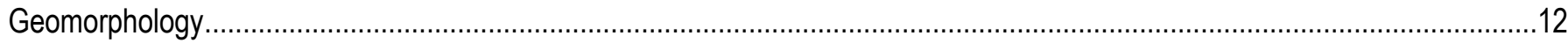

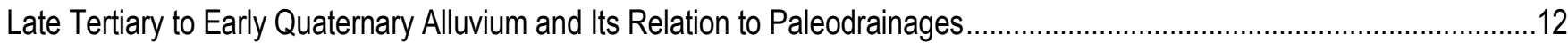

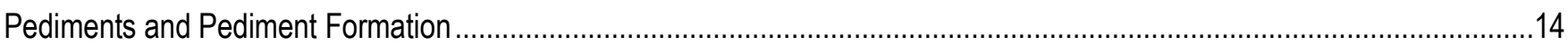

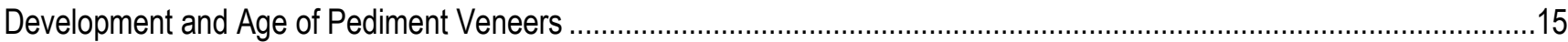

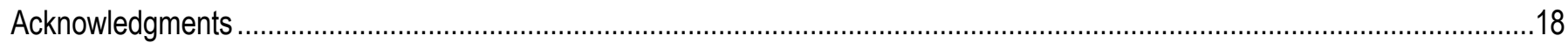

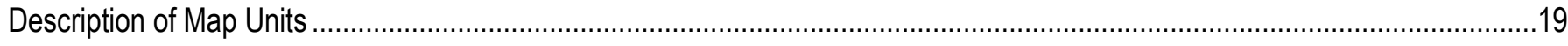

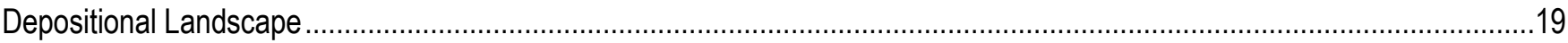

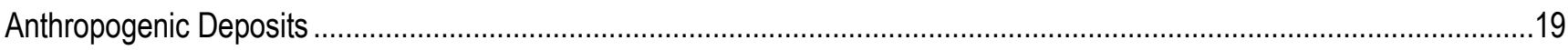

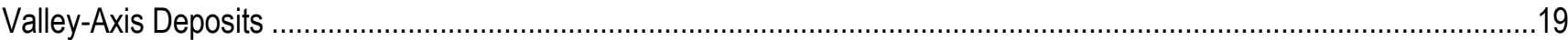

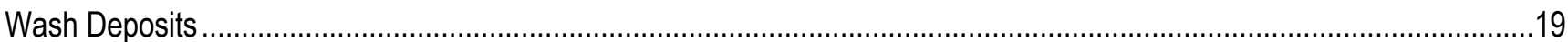

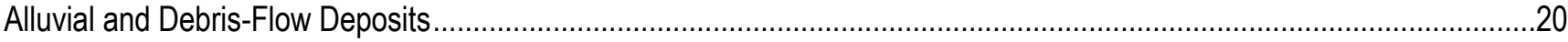

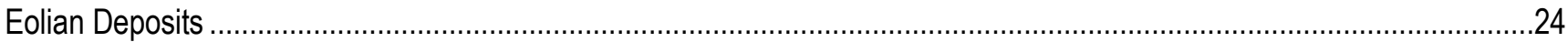

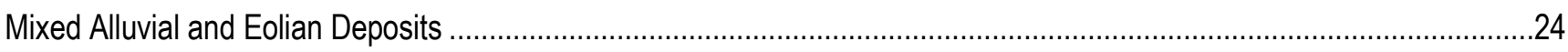

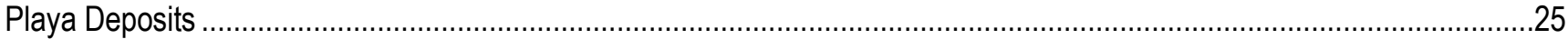

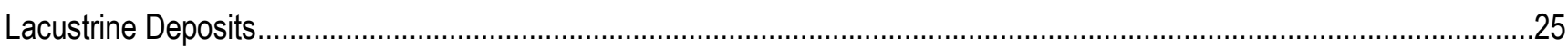

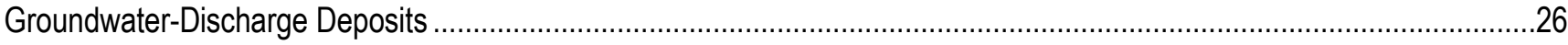




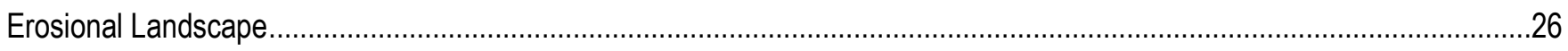

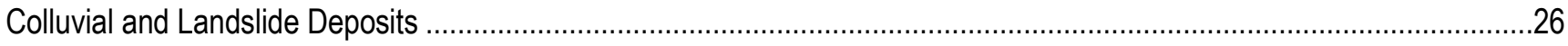

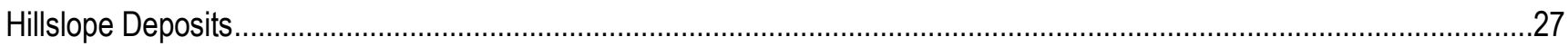

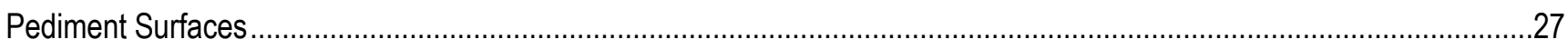

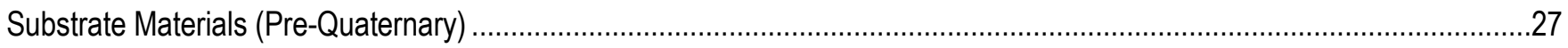

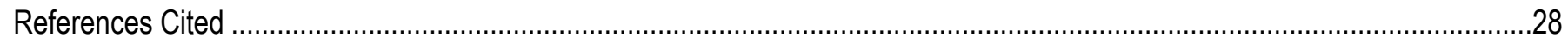

\section{Figures}

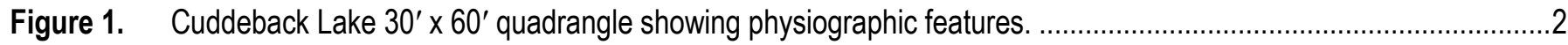

Figure 2. Sketch showing the present alluvial fan surface, the dip of the Pliocene alluvium fan deposits, and the El Paso

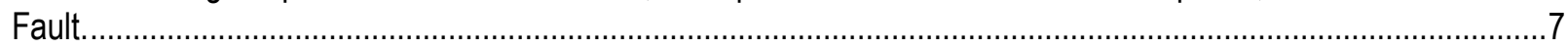

Figure 3. Tilted late Pliocene alluvial fan deposits capped by middle or late Pleistocene (Qoa) alluvial fan deposits.............7

Figure 4. Lockhart Fault and small middle to late(?) Holocene playa created by damming a small south-flowing drainage....10

Figure 5. Small Holocene playa filling a depression created by a right stepover of the Lockhart Fault................................11

Figure 6. Road cutbank exposing pedogenic, carbonate-cemented, extremely old alluvium (QToa) showing Stage V

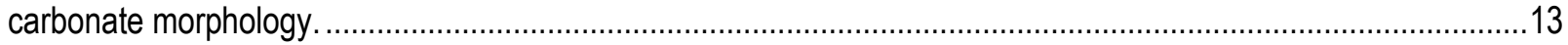

Figure 7. Roadcut showing a channel filled with polymict QToa gravel that is cut into granodiorite...................................14

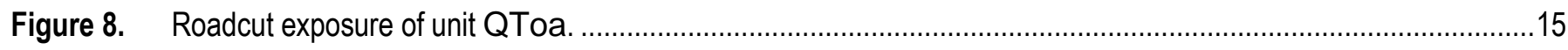

Figure 9. View southwest of small hill ( $\sim 30 \mathrm{~m}$ high) underlain by granodiorite and capped by unit QToa gravels. ...............16

Figure 10. View northwest of a subtle expression of the Muroc Fault and degraded scarp in the middle distance. .................17

Figure 11. View northwest of carbonate debris exposed during retreat from the Muroc Fault scarp....................................17

Figure 12. Photograph showing residuum developed on weathered granite slope............................................................18

\section{Tables}

Table 1. Characteristics of known or probable Quaternary faults. 


\title{
Surficial Geologic Map of the Cuddeback Lake 30' x 60' Quadrangle, San Bernardino and Kern Counties, California
}

\author{
By Lee Amoroso and David M. Miller
}

\begin{abstract}
The 1:100,000-scale Cuddeback Lake quadrangle is located in the western Mojave Desert north-northeast of Los Angeles, between the southern Sierra Nevada and San Bernardino Mountains, in Kern and San Bernardino Counties, California. Geomorphic features include highrelief mountains, small hills, volcanic domes, pediments, broad alluvial valleys, and dry lakes. It is one in a series of surficial geologic maps created to investigate landscape development and tectonic evolution of the northern Mojave Desert. The mapped area includes pre-Tertiary plutonic, metavolcanic, metasedimentary, and igneous rocks; Tertiary sedimentary and volcanic rocks; and Quaternary sediments and basalts. The map area includes the El Paso, Lockhart, Blackwater, and Muroc Faults, as well as the central segment of the Garlock Fault Zone. The tectonically active western Mojave Desert and the variety of surficial materials have resulted in distinctive geomorphic features and terrains.

Geologic mapping shows that active faults are widespread and have diverted drainage patterns. The tectonically active area near the Garlock Fault Zone and the nearby El Paso Fault influenced development of drainage networks; base level is controlled by fault offset. Evidence of a late Tertiary drainage network is preserved in remnants of alluvial fans and paleodrainage deposits north of the El Paso Mountains, west of the Lava Mountains, and south and west of the Rand Mountains. Holocene fault activity for the Cantil Valley, Lockhart, Garlock, and Rand Mountain Faults is indicated by displaced stream channels, playa-filled depressions, scarps, and shutter ridges. Previously unmapped Holocene and Late Pleistocene fault strands identified near the Rand Mountains may represent a splay at the northwest termination of the Lockhart Fault. The Grass Valley Fault, northwest of Black Mountain, is a right-lateral, strike-slip fault that may be a splay of the Blackwater Fault. Holocene activity on the Grass Valley Fault is indicated by one displaced early Holocene stream terrace. Mapped faults in Fremont Valley are tentatively identified as surficial expressions of the buried Cantil Valley Fault.
\end{abstract}

\section{Introduction}

The Cuddeback Lake quadrangle is located in the western Mojave Desert within the Basin and Range physiographic province, between long $117^{\circ}$ and $118^{\circ} \mathrm{W}$. and lat $35^{\circ}$ and $35^{\circ} 30^{\prime} \mathrm{N}$. Surficial geologic mapping included aerial-photographic interpretation and on-ground mapping. Restricted areas of the Naval Air Warfare Center China Lake and Cuddeback Lake Air Force Gunnery Range were mapped by aerial-photo interpretation only. This map supersedes a previously released surficial geologic map (Amoroso and Miller, 2006), primarily by improving the cartographic presentation to be more uniform at the scale of 1:100,000.

The mapping is concentrated on areas with late Tertiary and Quaternary deposits. Much of the area is low-relief desert that surrounds small mountains and bedrock knolls and hills. The region is distinguished by interior drainage; major and minor drainages empty into large playas 
including Cuddeback Lake, Koehn Lake, and Harper Lake. All these topographic depressions show evidence of tectonic control of their orientation and shape. Small playas are found along faults having a vertical component of displacement that affects drainage patterns.

The climate is arid and exhibits a wide range of daily and seasonal temperature variation. Maximum summer temperatures regularly exceed $38^{\circ} \mathrm{C}$, while the low winter temperature is about $-8^{\circ} \mathrm{C}$. Precipitation primarily comes from Pacific frontal storms; summer rains are infrequent. The western Mojave Desert region is not greatly affected by monsoonal wind-shifts and accompanying convection-driven storms (Rowlands, 1995).

\section{Geologic Setting}

The western Mojave Desert region is tectonically a triangular fault block, defined by Hewett (1954a) as the Mojave Block. This block is bounded by the left-lateral Garlock Fault that strikes northeast through the northern Cuddeback Lake quadrangle and separates the Mojave Block (to the south) from the Sierra Nevada to the north and the Great Basin to the northeast. The Mojave Block is bounded to the south by the right-lateral San Andreas Fault Zone, south of the map area. The Mojave Block is cut by numerous, discontinuous late Cenozoic strike-slip faults named the "Mojave strike-slip province" (Miller and Yount, 2002); a smaller part of the Mojave block was termed the "eastern California Shear Zone" by Dokka and Travis (1990). The Lockhart, Gravel Hills-Harper Lake, and Blackwater Faults, discussed in the Neotectonics section, are in the western part of the Mojave strike-slip province. The faults and many of the physiographic features discussed in this report are identified on figure 1.

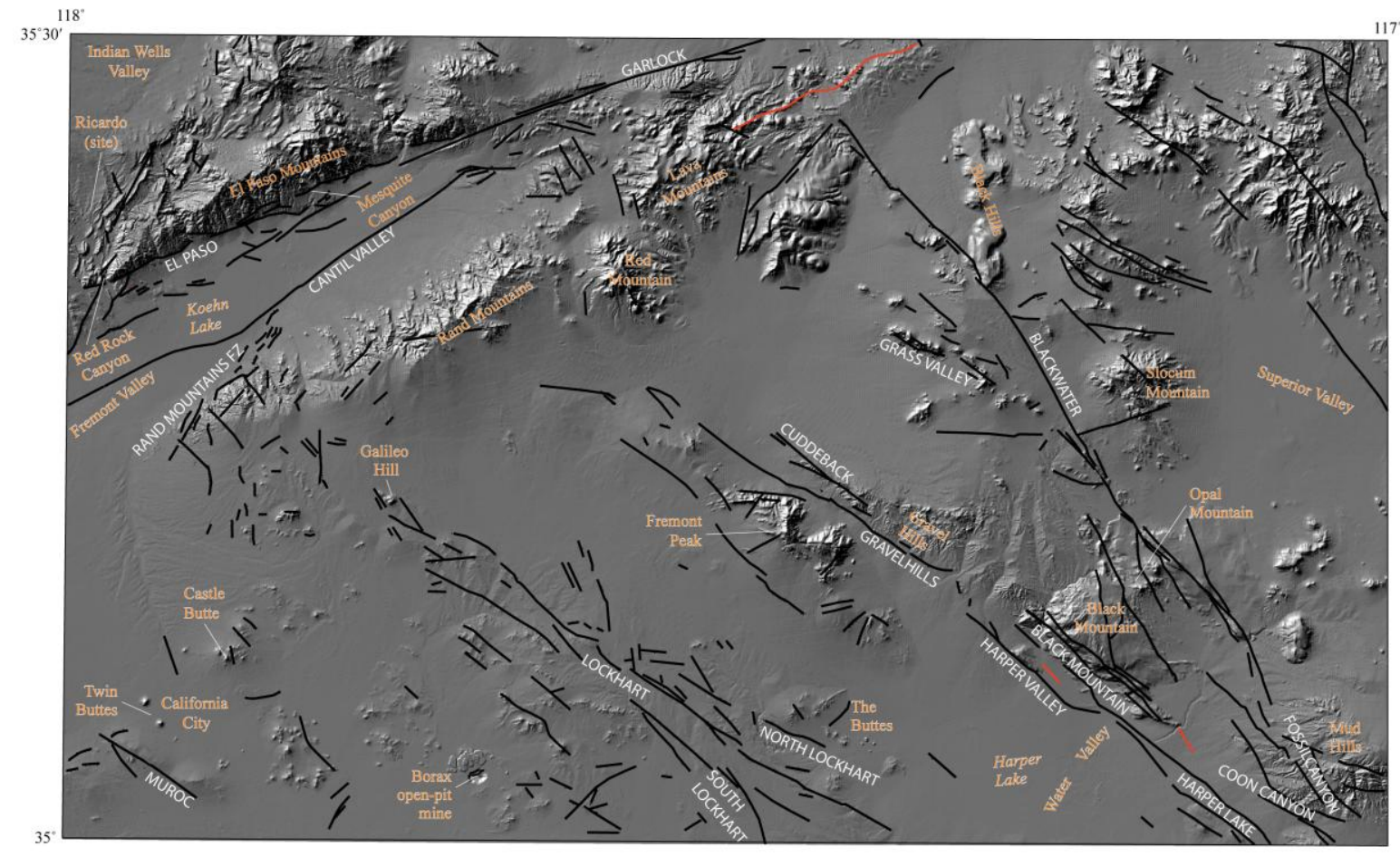

Figure 1. Cuddeback Lake $30^{\prime} \times 60^{\prime}$ quadrangle showing physiographic features (orange), faults and lineaments (black), folds (red), and fault names (white) on a hillshade map created from a 30-m DEM. FZ, Fault Zone. 
The pre-Quaternary geology is composed of pre-Tertiary mafic and felsic igneous and metamorphic rocks and Tertiary sedimentary and volcanic rocks. The pre-Quaternary materials control erosion and weathering rates, relief, and grain size of Quaternary deposits and are, therefore, classified into groups. Dibblee (1967) classified the pre-Tertiary rocks into four broad categories. High-pressure/temperature-regime metamorphic rocks are mostly Paleozoic and Precambrian schist, mylonite, and gneiss found in the El Paso and eastern Rand Mountains and The Buttes area (Cox and Diggles, 1986; Glazner and others, 1994). Metasedimentary rocks that include marble, phyllite, chert, quartzite, and conglomerate are found in the eastern El Paso Mountains and The Buttes area (Carr and others, 1997; Cox and Diggles, 1986; Fletcher and others, 2002). Shallow-depth intrusive rocks and metavolcanic rocks, mainly coarse to fine grained, are found in the El Paso Mountains. Plutonic rocks consist of widely distributed Mesozoic granites and also early Mesozoic granitic rocks in the western and far eastern parts of the El Paso Mountains.

Tertiary sedimentary rocks are mainly continental conglomerate, sandstone, shale, and limestone. These deposits are thickest in the El Paso Basin. There, Tertiary rocks of the Goler and Ricardo Formations unconformably overlie plutonic and metamorphic rocks along the north side of the El Paso Mountains and were gently tilted to the northwest between the middle Paleocene and early Miocene (Loomis and Burbank, 1988). Thick deposits of Tertiary sedimentary rocks also lie northeast of the Lava Mountains. Tertiary volcanic rocks in the Lava Mountains area include silicic tuff and breccia and rhyolite to basalt lava flows and plugs. Widespread Tertiary volcanic rocks, mainly mafic, occur to the east, south, and southeast of the Lava Mountains and the Red Mountain area (Smith and others, 2002). Small Tertiary mafic eruptive centers overlie Tropico Group sedimentary rocks (Oligocene? to Miocene) in the southwestern part of the quadrangle (Dibblee, 1967).

Quaternary sediments are the most areally extensive deposits found in the Cuddeback Lake quadrangle; they are distributed from the desert floor to high mountain slopes. Alluvium and colluvium, derived from the hills and mountains, mantle the hillslopes and piedmont areas.

Pleistocene and Holocene alluvial fan and terrace deposits consist of gravel to boulder-size clasts, sand, silt, and clay. The distal fans grade into fine-grained, valley-axis deposits. In many parts of the quadrangle, thin veneers of Late Pleistocene and Holocene eolian sand are found in the modern downwind direction from dry lakes and ephemeral drainages.

Major playas and saline lakes lie in depressions within the quadrangle: Koehn Lake south of the El Paso Mountains within Fremont Valley, Cuddeback Lake south of the Lava Mountains, Harper Lake southwest of Black Mountain, and Superior Lake northeast of Opal Mountain in the Superior Valley. These are all likely tectonically controlled depressions, although some of the bounding faults are obscured by thick alluvial deposits.

\section{Previous Work}

The geology of the Cuddeback Lake quadrangle area has been studied since 1902. Before 1952, much of the work involved describing the groundwater resources (Thompson, 1929) and mineral-resource potential. Pack (1914) looked at the oil potential in the Harper Valley area, Hulin (1925) described the mineral potential and geology of the Randsburg 15-minute quadrangle, and Gale (1946) reported on the Kramer borate district. Geologic maps of several 15-minute quadrangles were produced by Dibblee (1952) and Dibblee and Gay (1952). Dibblee published geologic maps and reports of the Saltdale quadrangle (Dibblee, 1952) and geologic maps of the Fremont Peak and Opal Mountain quadrangles (Dibblee, 1968). Hewett (1954a,b) described the general geology and faults of the Mojave Desert. Jennings and others (1962) produced a 1:250,000scale geologic map of the Trona sheet that encompasses the Cuddeback Lake quadrangle. Dibblee 
(1967) includes a comprehensive report and compiled geologic maps of the area north of the San Andreas Fault to the town of Inyokern and east to the 117 th meridian, more than $18,000 \mathrm{~km}^{2}$ of the western Mojave Desert region. Clark (1973) produced maps identifying recent activity on the Garlock Fault and associated faults. Several detailed studies were conducted within the El Paso Mountains area including Loomis (1984), Cox and Diggles (1986), and Carr and others (1997). Work in the Lava Mountains area includes Smith (1964), Keenan (2000), Smith and others (2002), and Smith (2009). Fletcher (1994) completed a field-based project on large-magnitude extension in the central Mojave Metamorphic Core Complex (The Buttes area), also discussed in Fletcher and others (1995).

\section{Mapping Methods}

The map was produced using remote-sensing interpretation of high-resolution aerial photography and processed Landsat 7 imagery combined with field verification of unit classification. Most of the bedrock geology was compiled from previous mapping (see Index to Mapping, map sheet). Mapped geology was transferred from aerial photographs to GIS by digitizing, using mosaics of digital orthophoto quadrangles. Digitizing at screen scales of 1:20,000 to 1:35,000 provided location accuracy. The area north and west of the El Paso Mountains to the quadrangle boundary and certain other areas of the Cuddeback Lake quadrangle were mapped at larger scale while studying pediments or neotectonics. This more detailed surficial geologic map was released previously (Amoroso and Miller, 2006).

Quaternary surficial deposits were classified using a combination of landform and sedimentology (Birkeland, 1999), inset relations, process geomorphology, height above the modern drainage system, and the degree of pedogenesis (Birkeland and others, 1991). Soil pits, 20-70 cm deep, were excavated or exposures along channel cutbanks were cleaned to examine the soils and determine pedogenesis-based age estimates. During field visits, data was collected to compare the surficial geology to the observed vegetation cover and species, distribution and amount of anthropomorphic disturbance, biological soil crust cover, particle-size analysis samples, mammal burrow density, and micro-topography. Ground and landscape photography was collected to document the appearance of the area. A calibrated color panel was included in the ground photographs for calibration of remote-sensing imagery.

\section{Explanation of Unit Labels}

Map-unit classification followed the approaches developed by Yount and others (1994), which described surficial deposits according to a matrix of process of deposition and age. In erosional environments, map units are classified by a combination of landform and surficial cover attributes, and age is generally not provided because the environments are spatially nonuniform with respect to age.

\section{Composite Unit Labels}

Surficial geologic units commonly form thin $(<2 \mathrm{~m})$ veneers over older surficial units and bedrock. In areas where this relation is common, the unit labels are shown separated by a slash (/). The younger, or overlying, unit is indicated first. Thus, Qya/Qoa indicates an area where a veneer of young alluvial fan deposits overlies old alluvial fan deposits, and Qya/fpg indicates an area where a veneer of young alluvial fan deposits (Qya) overlies felsic grus-forming granite (fpg).

The lateral extent of individual deposits is commonly so small that each deposit cannot be shown individually at map scale. Areas made up of deposits too small to show at map scale (representing more than $20 \%$ of the area) are indicated by unit labels separated by a plus sign (+), 
and the most common deposit is listed first. Thus, Qya+Qia indicates an area containing both Qya and Qia deposits, and Qya is more common than Qia; other deposits in the area compose less than 20 percent.

\section{Conventions for Erosional Environments}

Erosional environments such as mountains and pediments are widespread and consist of thin surficial sediment distributed irregularly among bedrock exposures. Materials in mountainous areas are largely formed in place by weathering of the bedrock but may be transported short distances by mass-wasting and fluvial processes. These materials are designated as "hillslope materials" regardless of transport mechanism. Thicker, areally consistent, and mappable hillslope sediment is distinguished as colluvium and landslide deposits. Pediments in this area are primarily Miocene in age but have continued to evolve into the Quaternary, because Quaternary deposits are associated with many pediment surfaces. Both pediment and hillslope deposits are indicated on the map with labels including the underlying bedrock type. Bedrock material is classified in ten map units based on chemical composition and weathering characteristics.

Pediments are erosional surfaces that present special challenges for mapping. They exhibit varying degrees of incision and cover by a sediment veneer, are formed in varying substrate rocks and deposits, and vary in age. Pediments are represented by two terms separated by a hyphen (-). The first term indicates the degree of dissection and the second term indicates substrate materials. Thus, Qpv-fpg indicates a veneered pediment (Qpv) cut into grus-forming felsic plutonic rock (fpg).

\section{Neotectonics}

\section{Blackwater Fault}

The 55-km-long Blackwater Fault and the Calico Fault (southeast of the map area) form the longest strike-slip fault in the Mojave Desert (Oskin and Iriondo, 2004). The southern end of the Blackwater Fault extends to within about $10 \mathrm{~km}$ of the Calico Fault just north of the Mud Hills where a complex left stepover apparently occurs. In this area, Late Pleistocene deposits display scarps, but Holocene deposits do not. The north end of the Blackwater Fault terminates within 5 $\mathrm{km}$ of the Garlock Fault where it may cut Holocene deposits locally (Oskin and Iriondo, 2004). This northwest-striking, right-lateral, strike-slip fault shows about $8.5 \mathrm{~km}$ of right separation in the Calico Mountains-Mud Hills area (Dokka, 1989). Oskin and Iriondo (2004) reinterpreted the age for the Black Mountain Basalt as 3.77 $\pm 0.11 \mathrm{Ma}$ and measured $1.8 \pm 0.1 \mathrm{~km}$ of displacement of the basalt to yield a long-term slip-rate estimate for the Blackwater Fault of $0.49 \pm 0.04 \mathrm{~mm} /$ year. Oskin and Iriondo (2004) concluded that the lack of evidence of Holocene fault rupture plus the evidence of rapid and transitory strain accumulation (Peltzer and others, 2001) supported a higher near-term seismic hazard posed by the Blackwater Fault. We found no new evidence for Holocene rupture along the Blackwater Fault and only a few places where scarps cut middle to late Pleistocene sediments (Qia); most scarps are degraded and affect middle Pleistocene sediments (Qia), early to middle Pleistocene sediments (Qoa), and Pliocene to early Pleistocene deposits (QToa). Faults that cut Late Pleistocene deposits lie along the southwest front of the Mud Hills in a position that may indicate a left stepover to the Harper Lake and Gravel Hills Faults and the consequent abandonment of the Blackwater Fault. In the Mud Hills, two faults inferred to be splays of the Blackwater Fault (Bryant, 1987) show evidence of Quaternary activity. The Fossil Canyon Fault and the Coon Canyon Fault offset middle and late Pleistocene alluvium. However, Reynolds and 
Fay (1989) reported fossil evidence within Holocene fissure fill along a section of the Coon Canyon Fault that suggests active tectonism.

\section{Cantil Valley Fault}

The Cantil Valley Fault is considered to be a splay of the western Garlock Fault segment (Louie and Qin, 1991). The 15-km-long fault has been identified by gravity studies and subsurface information (Louie and Qin, 1991; Mabey, 1960; Pampeyan and others, 1988). The fault has little surface expression except for a zone of scarps at the northeast end of Fremont Valley, located near the inferred fault trace. Offset unit Qoa deposits near the northeast termination are likely related to the Cantil Valley Fault. Pampeyan and others (1988) suggested that Cantil Valley Fault and the smaller faults found southwest, south, and southeast of Koehn Lake are probably part of the Garlock Fault Zone. Holocene deposits are cut by scarps in several places and are inferred in other places where fluvial erosion may have enhanced the scarp. Two small Holocene playas found near the northeast end of the presumed fault trace may be the result of deformation on this fault.

\section{El Paso Fault}

The El Paso Fault, located along the linear southern flank of the El Paso Mountains, is a 32km-long, down-to-the-south normal fault and is considered a strand of the Garlock Fault (Dibblee, 1952; Loomis and Burbank, 1988). The vertical displacement was estimated by Dibblee (1952) to be about 3,000 m. This fault displays evidence of activity during the Pleistocene and Holocene. Gravelly alluvium derived from the El Paso Mountains and exposed along lower Mesquite Canyon has remained in place with respect to its source for most of the Quaternary (Carter, 1980). This late Pliocene alluvium (Carter, 1994), is tilted as steep as $13^{\circ}$ northwest towards the fault either due to normal slip along a listric fault or to movement along (concealed) faults within the hanging wall. Normal fault displacement caused base-level changes on the Last Chance Canyon drainage during the Quaternary. Deposits near there show significant vertical separation resulting from the baselevel fall. Late Pleistocene (Qia) terrace/alluvial deposits lie $15 \mathrm{~m}$ above the active channel and middle Pleistocene (Qoa) deposits lie $35 \mathrm{~m}$ above the active channel. Older Holocene terrace deposits (Qyw) lie $3 \mathrm{~m}$ above the active channel. Carter (1980) observed no evidence of modern lateral movement on the El Paso Fault. However, during a field reconnaissance in a canyon $1.5 \mathrm{~km}$ northeast of the town of Garlock, middle to late Pleistocene terrace deposits were observed to show left-lateral displacement along splays of the El Paso Fault. No paleoseismic studies of the El Paso Fault have been done, but a rough estimate of the vertical slip rate can be made from the Mesquite Canyon observations (fig. 2). The perpendicular distance from the observed $13^{\circ}$ dip location to the El Paso Fault trace is about $650 \mathrm{~m}$, and the modern surface slopes about $4.5^{\circ}$. A total of about $17.5^{\circ}$ of rotation has occurred relative to the location of the observed dip (fig. 3). This calculates to roughly $200 \mathrm{~m}$ of movement on the normal fault. If fault movement were initiated about $2 \mathrm{Ma}$, during the deposition of the fan alluvium, this time interval would yield a slip rate of $\sim 0.1$ $\mathrm{mm} /$ year.

\section{Garlock Fault}

The Garlock Fault is a broadly arcuate zone of northeast-striking, mainly left-lateral faults extending northeast $248 \mathrm{~km}$ from the San Andreas Fault near Old Fort Tejon to the south end of Death Valley. Fault locations were identified by aerial photographic inspection and the literature (Clark, 1973; McGill and Rockwell, 1998; McGill and Sieh, 1991, 1993). An estimated 48 to 74 $\mathrm{km}$ of left slip was documented for this fault zone (Carr and others, 1993; Davis and Burchfiel, 1973; Loomis and Burbank, 1988; Michael, 1966). Estimates of initial movement on the Garlock 


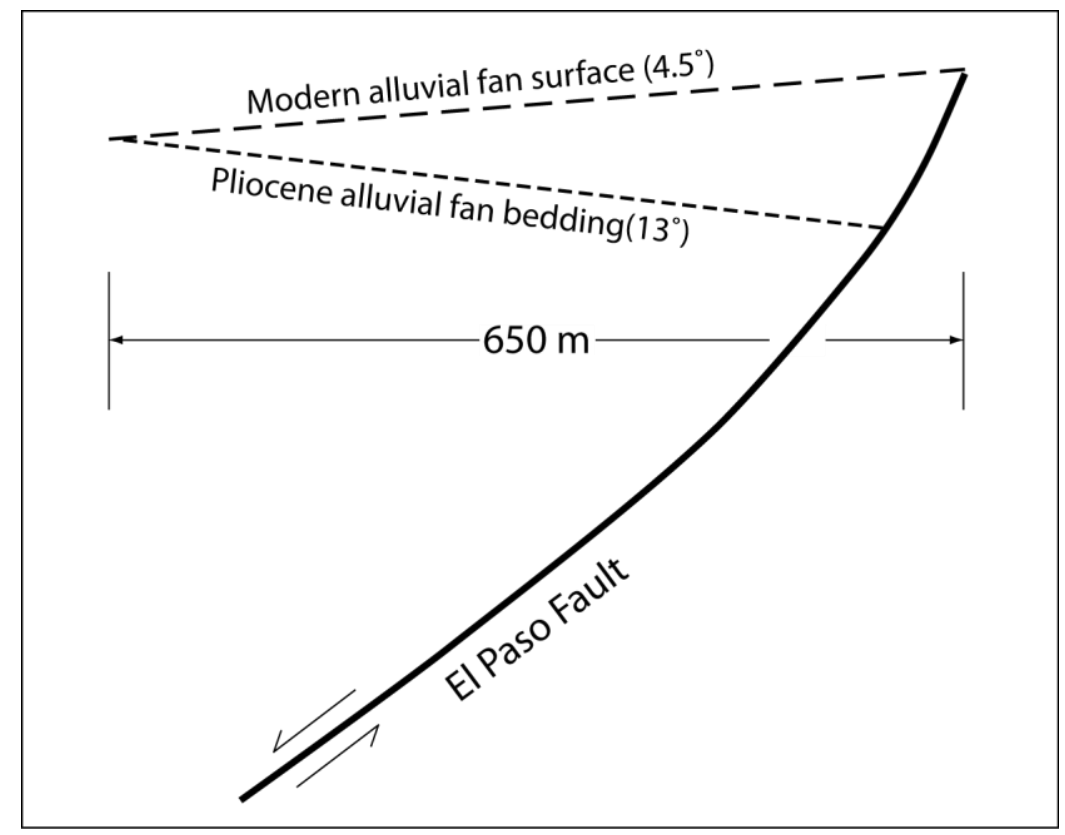

Figure 2. Sketch showing the relation of the present alluvial fan surface, the dip of the Pliocene alluvium fan deposits, and the El Paso Fault. The drawing is not to scale, and the actual dip on the fault is not known.

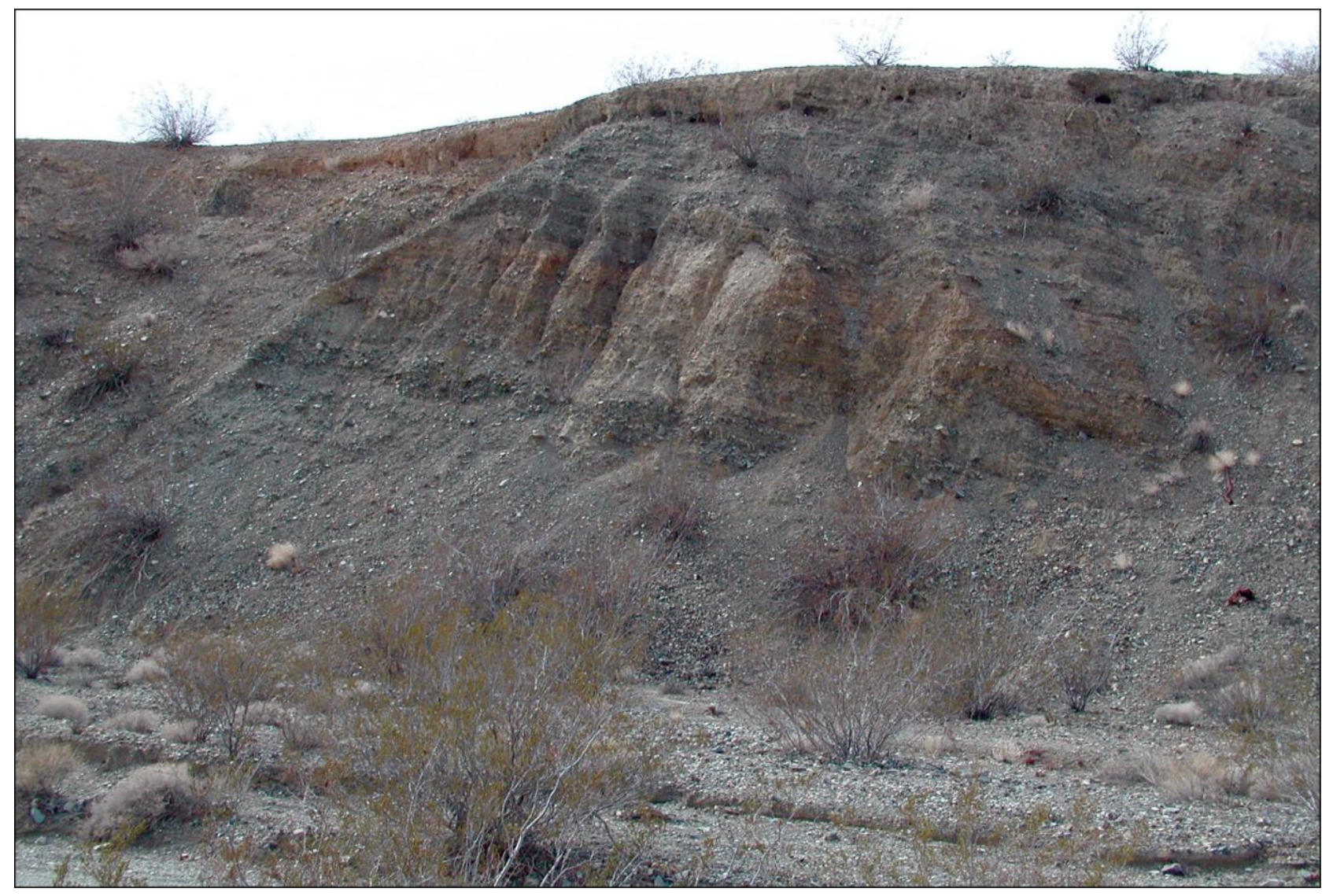

Figure 3. Photograph of deposits illustrated in figure 2. View southwest of tilted late Pliocene alluvial fan deposits capped by middle or late Pleistocene (Qoa) alluvial fan deposits. The erosional scarp is about $15 \mathrm{~m}$ high. The tilted sediments dip towards the El Paso Mountains Fault. A Stage IV morphology soil carbonate was developed in the capping alluvium. Photographed in lower Mesquite Canyon in 2002. 
Fault include the early Miocene (Louie and Qin, 1991), late Miocene (Loomis and Burbank, 1988), post-early Miocene (Monastero and others, 1997), and early middle Miocene (Smith and others, 2002); slip has continued into the late Quaternary. The left-lateral displacement of the Garlock Fault is well established (Davis and Burchfiel, 1973; Dibblee, 1952; Dibblee and Gay, 1952; Michael, 1966). In the Cuddeback Lake quadrangle, evidence for left-lateral displacement of Holocene alluvial deposits and drainages, as well as Pleistocene terrace deposits and shutter ridges, are well exposed from north of Koehn Lake to the town of Garlock. Folds associated with the Garlock Fault affect Pleistocene deposits east of Red Rock Canyon and northeast of the Lava Mountains, where the Christmas Canyon Formation is deformed (Smith, 1991). The Christmas Canyon Formation is attributed by Smith (1991) as being Pleistocene in age.

The formation of Fremont Valley between the El Paso and Rand Mountains (fig. 1), which created the Koehn Lake (Cantil) Basin, is suggested to be the result of a dilatational left stepover on the Garlock Fault (Aydin and Nur, 1982; Westaway, 1995). An alternative hypothesis to explain the Cantil Basin extension is a proposed interaction between the Garlock and the right-lateral Lockhart-Helendale Faults, resulting in the counterclockwise rotation of tectonic blocks in the western Mojave Desert (Carter and others, 1987; Louie and Qin, 1991).

The Garlock Fault was divided into segments by McGill and Sieh (1991); the west segment extends west from the Koehn Lake stepover to the San Andreas Fault, and the central segment extends from that stepover eastward. Slip-rate estimates have been made for several locations along the western and central segments. Paleoseismic investigation on the western Garlock Fault (just west of the Cuddeback Lake quadrangle) determined that the early Holocene slip rate was about 6 $\mathrm{mm} / \mathrm{yr}$ (McGill and others, 2009). Carter (1980) used displaced gravel fans, $7 \mathrm{~km}$ east of Koehn Lake, to estimate a Pleistocene slip rate of about $12 \mathrm{~mm} / \mathrm{yr}$ and an average Holocene rate of 7-8 $\mathrm{mm} / \mathrm{yr}$. McGill and Sieh $(1991,1993)$ estimated that the Late Pleistocene slip rate in the central Garlock Fault segment was $\sim 5-7 \mathrm{~mm} / \mathrm{yr}$.

The Garlock Fault cuts early Pleistocene to late Holocene alluvial fan, playa, and lacustrine deposits from Mesquite Canyon to east of Hwy 395. Holocene drainages show left-lateral offset or are blocked by shutter ridges, which are especially noticeable near Mesquite Canyon. Fault stepovers created closed basins that are filled with Holocene alluvium.

\section{Grass Valley Fault}

The Grass Valley Fault is the informal name for a 9-km-long zone of right-lateral, strikeslip faults found along a line of low rhyolite hills west of Grass Valley. The slip sense is shown by offset drainages, beheaded alluvial fans, and offset shutter ridges. This fault displaces extremely old alluvial deposits (QToa), old alluvial deposits (Qoa), intermediate-age alluvial deposits (Qia), and perhaps older young alluvial deposits (Qyao) by different amounts, implying tectonic activity throughout the Quaternary. There is an estimated $370 \mathrm{~m}$ of right-lateral slip based on displacement of an alluvial fan (QToa) from a large drainage. The Grass Valley Fault may be a splay of the Blackwater Fault, but no evidence of surface ruptures was found between the two faults.

\section{Harper Fault Zone}

The Harper Fault Zone is a zone of short, primarily right-lateral strike-slip faults including, from northwest to southeast, the Cuddeback Fault, Gravel Hills Fault, Harper Valley Fault, Black Mountain Fault, and Harper Lake Fault. 


\section{Cuddeback Fault}

The 4.5-km-long Cuddeback Fault was mapped by Dibblee (1968) as a right-lateral, strikeslip fault. The fault displaces Tertiary Barstow Formation (represented on the map as Qha/pc) and does not show evidence of Holocene activity.

Gravel Hills Fault

The Gravel Hills Fault is a 16-km-long, right-lateral, oblique fault with significant up-tothe-northeast displacement (Dibblee, 1968). The amount of strike-slip offset is not well constrained; Dibblee (1968) suggested that the axis of the Gravel Hills Syncline has been displaced by $\sim 0.8 \mathrm{~km}$. Evidence of Holocene movement includes (1) displaced Holocene alluvium at several places along the Gravel Hills Fault northeast of Fremont Peak, (2) offset modern stream channels, and (3) a small closed depression containing an active playa that borders the fault.

Harper Valley Fault

The Harper Valley Fault, southwest of Black Mountain, is a northwest-striking fault with up-to-the-northeast vertical displacement (Dibblee, 1968). This fault offsets a range of geologic units, from Pliocene basalts to Holocene alluvium. Drainages show evidence of gradient changes where they cross the fault. No strike-slip displacement was noted.

\section{Black Mountain Fault}

The Black Mountain Fault is an approximately 30-km-long, northwest-trending zone of high-angle faults, exhibiting right-lateral strike slip, mapped by Dibblee (1968). Dibblee (1968) estimated about $0.8 \mathrm{~km}$ of right-lateral offset based on displacement of the Black Mountain Anticline and as much as $600 \mathrm{~m}$ of down-to-the-southwest vertical offset. The Black Mountain Fault displaces the Black Mountain Basalt, which has yielded dates of 2.55 $\pm 0.58 \mathrm{Ma}$ (Burke and others, 1982) and 3.77 $\pm 0.11 \mathrm{Ma}$ (Oskin and Iriondo, 2004). There is little evidence of Late Pleistocene activity on this fault; Bryant (1987) reported that an old, presumably Late Pleistocene shoreline of Harper Lake is not offset by the Black Mountain Fault. The Black Mountain Fault cuts old alluvial deposits (Qoa) and intermediate-age alluvial deposits (Qia) but does not appear to cut Holocene deposits.

Harper Lake Fault

The Harper Lake Fault is likely the continuation of the Black Mountain Fault (Bryant, 1987). South of Black Mountain, several faults form a broad zone within which Pleistocene deposits are offset and early Holocene deposits are folded.

\section{Lockhart Fault Zone}

The Lockhart Fault Zone consists of the subparallel Lockhart, South Lockhart, and North Lockhart Faults. Although surface traces are discontinuous (Dokka and Travis, 1990), geomorphic and seismic evidence suggest that the Lockhart Fault is a continuation of the Lenwood Fault and the South Lockhart Fault is the northwestern extension of the Helendale Fault south of the map area (Dibblee, 1985; Louie and Qin, 1991; Page and Moyle, 1960; Schell, 1994). 


\section{Lockhart Fault}

The 40-km-long, right-lateral, strike-slip Lockhart Fault extends from just west of Barstow to the southern flank of the Rand Mountains. Dibblee (1968) stated that the fault is right lateral and strike slip, but the amount of displacement is not known (Dokka and Travis, 1990). The fault has a down-to-the-northeast component that is most apparent east of U.S. Hwy 395. West of Hwy 395, the fault trace is manifested as a dissected scarp or is aligned with a broad erosional trough (Bryant, 1987). The fault displaces Quaternary alluvium and places Holocene against Late Pleistocene deposits east of Hwy 395 (Bryant, 1987). The creation of a small middle to late(?) Holocene playa (fig. 4) due to $\sim 30 \mathrm{~cm}$ of uplift that dammed a small drainage suggests that this fault was active during much of the Holocene. A right stepover of the Lockhart Fault, $600 \mathrm{~m}$ southeast of the playa, created another Holocene playa (fig. 5).

The Lockhart Fault splays just west of U.S. Hwy 395 and creates a small playa near the splay termination. The main fault continues farther northwest, becomes discontinuous, and terminates in a broad splay of faults and lineaments near the Rand Mountains. During a paleoseismic trenching investigation, Schell (1994) observed that some north- and north-northwesttrending lineaments mapped on the Rand Mountains pediment appear to be faults exhibiting evidence of Holocene rupture. The north-striking faults and small grabens in the western part of the Rand Mountain pediment may also be related to the Lockhart Fault Zone or may be the result of interaction between the Lockhart Fault and normal faults that bound the northern part of the Rand Mountains.

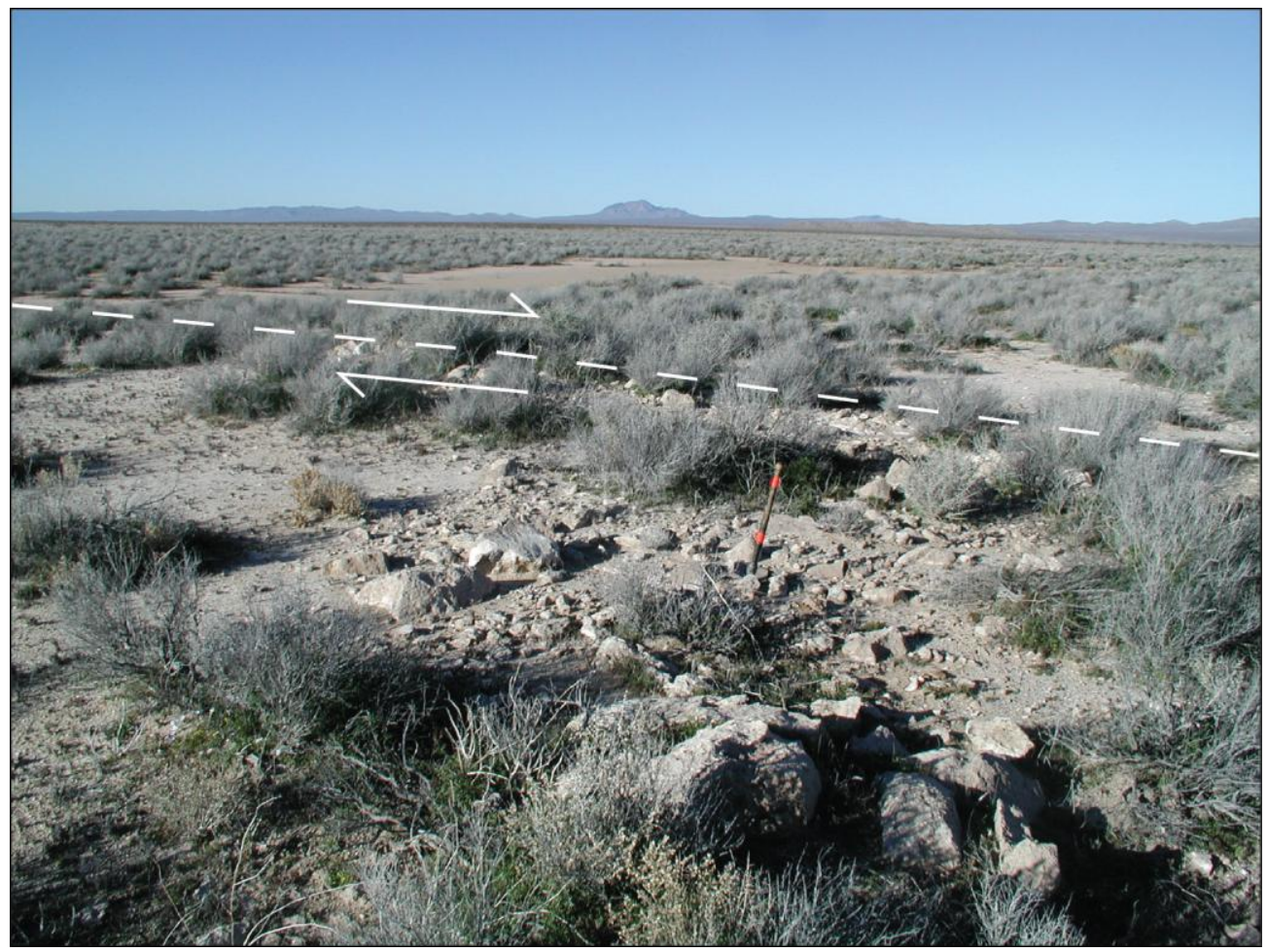

Figure 4. Looking northwest across the Lockhart Fault at small middle to late(?) Holocene playa created by damming a small south-flowing drainage at far left. A jumble of soil carbonate fragments in grus-rich alluvium (Qoag), likely derived from outcrops $600 \mathrm{~m}$ to the southeast, lie on the upthrown side of the fault. Relief across the fault is approximately $30 \mathrm{~cm}$. The low-elevation Rand Mountains are seen at upper left and the more prominent Red Mountain in the upper center of the photograph. Shovel handle is $50 \mathrm{~cm}$ long. 


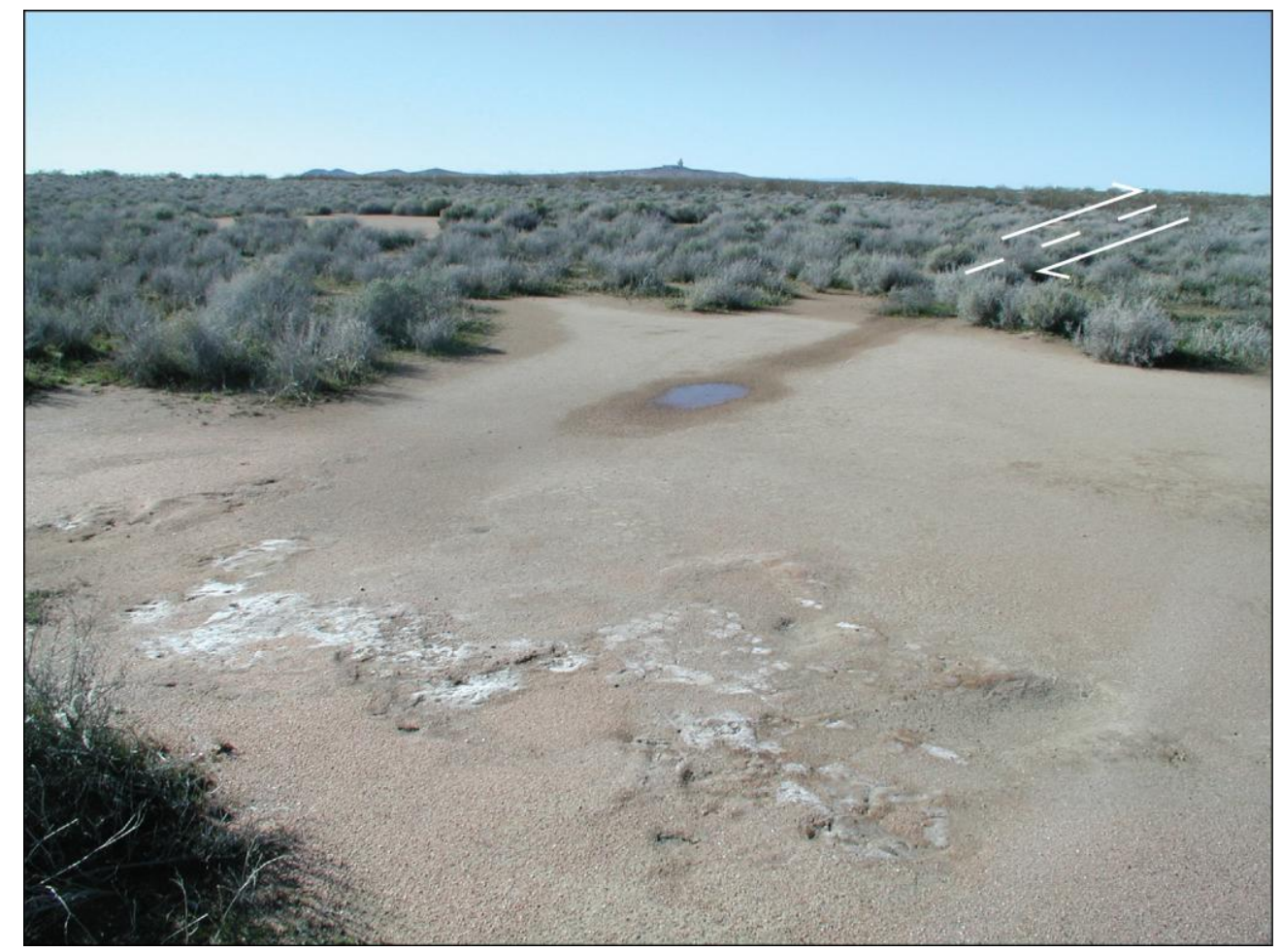

Figure 5. Small Holocene playa filling a depression created by a right stepover of the Lockhart Fault about $600 \mathrm{~m}$ southeast of the location shown in figure 4. The approximate trace of the Lockhart Fault is shown; the fault trace steps approximately $100 \mathrm{~m}$ to the left of the playa.

\section{South Lockhart Fault}

The South Lockhart Fault is a 27-km-long north- to northwest-striking fault. The fault trace is discontinuous and the vertical displacement varies from down-to-the-south to down-to-the-north. Unit QToa alluvial gravel deposits, located $11 \mathrm{~km}$ northwest of the Boron Air Force Station, are found on either side of the fault. These deposits appear to be offset by a minimum of $1 \mathrm{~km}$. There is no evidence of displaced streams along the South Lockhart Fault.

\section{North Lockhart Fault}

The 6-km-long North Lockhart Fault was classified as right lateral and strike slip by Dibblee (1968). This fault shows down-to-the-north vertical displacement near its southeast end. The fault offsets middle to late Pleistocene alluvial deposits and places middle Pleistocene against Holocene alluvium at the southeast end of the fault.

\section{Muroc Fault}

The main 8-km-long Muroc Fault shows a down-to-the-southwest offset and places bedrock against Late Pleistocene to Holocene(?) grussy alluvium. Subsidiary faults show west-northwest to northeast orientations and several senses of offset.

\section{Rand Mountains Fault Zone}

The Rand Mountains Fault Zone is a set of normal faults (Pampeyan and others, 1988) along the north, dissected flank of the Rand Mountains. The zone of northeast-striking faults places granite against alluvium in the southwestern part of the range. Farther to the northeast, the faults 
cut alluvium on the piedmont, where middle to late Pleistocene alluvium is offset down-to-thenorth as much as $2.5 \mathrm{~m}$; Holocene alluvium is offset as much as $1.2 \mathrm{~m}$. These faults may not be related to the extension at the stepover of the Garlock Fault because they lie outside the overlap zone, which lies farther north in the Fremont Valley.

Table 1. Characteristics of known or probable Quaternary faults.

[Unit Qia1 is a subdivision of unit Qia and is approximately $30 \mathrm{ka}$. Unit Qyag2 is a subdivision of unit Qyag and is approximately 20-200 yr. Unit Qyag1 is a subdivision of unit Qyag and is approximately 5-50 yr. Unit Qya4 is a subdivision of unit Qya and is about 15-9 ka]

\begin{tabular}{|c|c|c|c|c|c|}
\hline \multirow{2}{*}{ Fault } & \multirow{2}{*}{ Strike } & \multicolumn{2}{|c|}{ Last rupture } & \multirow{2}{*}{ Striae } & \multirow{2}{*}{ Geomorphic expression } \\
\hline & & Unit cut & Unit uncut & & \\
\hline Garlock & 070 & Qya & Qaa & none & $\begin{array}{l}\text { scarps, offset drainages, linear } \\
\text { mountain front }\end{array}$ \\
\hline El Paso & 065 & Qia & Qya & none & linear mountain front, scarps \\
\hline Blackwater $^{1}$ & 325 & Qoa & Qia1 & none & linear hill, scarp \\
\hline Cantil Valley & 055 & Qoa & Qya & none & low-angle scarps, playas? \\
\hline Grass Valley & 300 & Qia & Qya4? & none & scarps, offset fans \\
\hline Gravel Hills & $300-320$ & QToa & Qia & none & linear hill, scarps to $8 \mathrm{~m}$ \\
\hline Harper Valley & 320 & Qya & Qaa & none & low scarps \\
\hline Muroc & 300 & Qiag & Qyag & none & scarps, linear white stripes \\
\hline Lockhart & 295 & Qyag & Qaag & none & $\begin{array}{l}\text { scarp, depressions and playas, } \\
\text { grabens }\end{array}$ \\
\hline North Lockhart & 300 & Qoa & Qia & none & scarps \\
\hline South Lockhart & 310 & QToa & Qiag & none & offset alluvial deposits \\
\hline $\begin{array}{l}\text { Rand Mountain } \\
\text { Fault Zone }\end{array}$ & $030-060$ & Qyag2 & Qyag1 & none & scarps $1-1.8 \mathrm{~m}$ high \\
\hline
\end{tabular}

${ }^{1}$ See section on Blackwater Fault that discusses more recent activity on inferred splays of that fault.

\section{Geomorphology}

\section{Late Tertiary to Early Quaternary Alluvium and Its Relation to Paleodrainages}

A linear, discontinuous pattern for late Tertiary to Early Pleistocene alluvial deposits suggests that they represent former drainages. They are classified as paleodrainages because the deposits either are found more than $15 \mathrm{~m}$ above the present base level or the deposits lie on bedrock that was not the source of the clasts. These remnants of late Tertiary to early Quaternary extremely old alluvial deposits (QToa) and a few middle Pleistocene old alluvial deposits (Qoa) are found north of the El Paso Mountains, west of the Lava Mountains, and south of the Rand Mountains.

The unit QToa deposits west of the Lava Mountains consist of rounded clasts of andesite and basalt. The top of the deposit is about $45 \mathrm{~m}$ above the present valley floor. The rounding of the clasts suggests they were fluvially transported westward from the Lava Mountains area. Matrix material between the clasts shows significant pedogenesis, with clayey, angular peds. The thickness and topographic expression of the bouldery deposit suggest transport of the clasts within a broad valley of moderate gradient that drained into the Neogene Cantil Basin (Koehn Basin of Dibblee, 1967). 


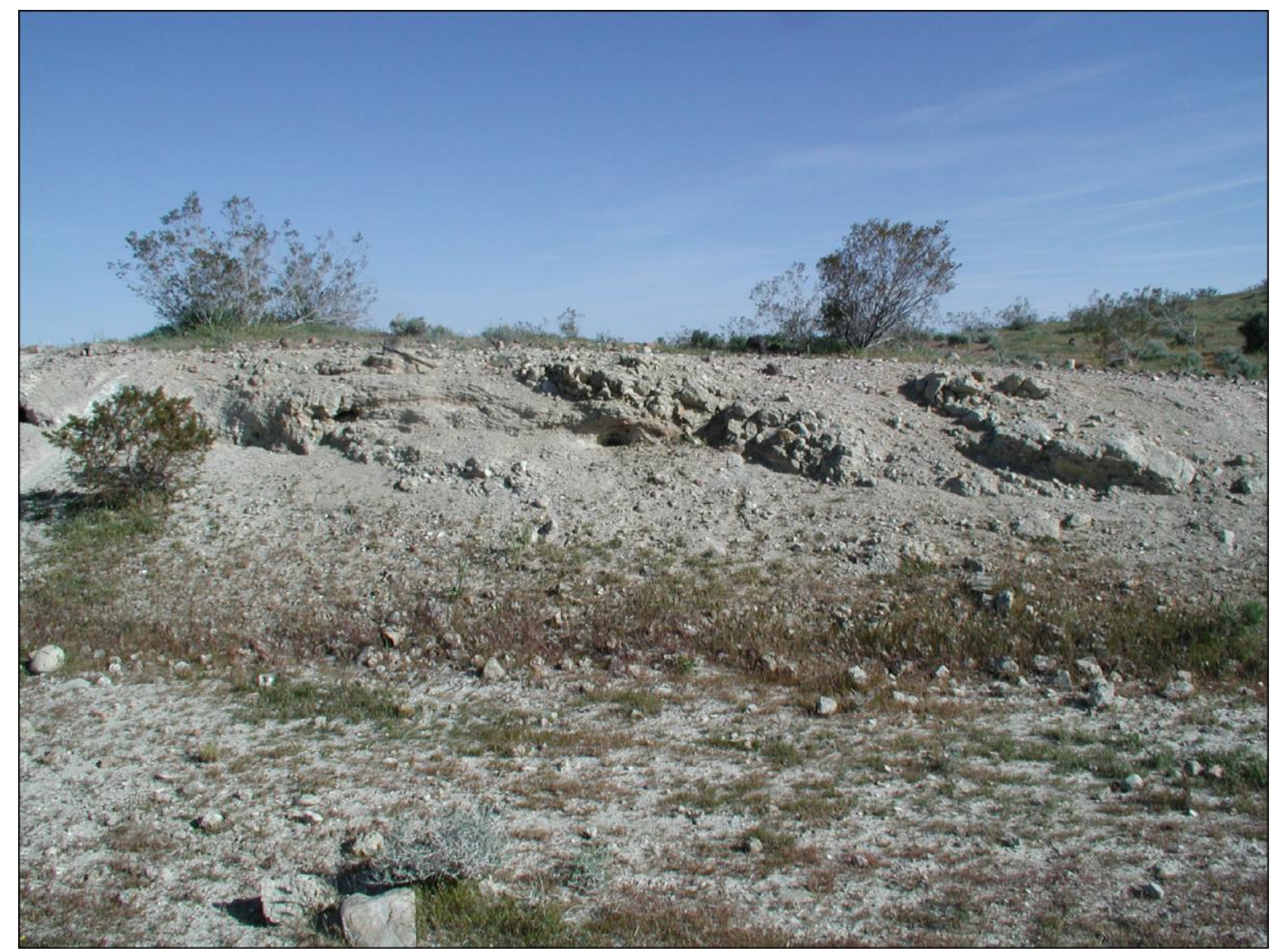

Figure 6. Road cutbank exposing pedogenic, carbonate-cemented, extremely old alluvium (QToa) showing Stage V carbonate morphology, which suggests these QToa deposits are at least early Pleistocene to Pliocene age (Machette, 1985). Imbrication measurements showed the stream flowed S. $44^{\circ} \mathrm{W}$.

Deposits of imbricated, well-rounded granite and other clasts (unit QToa) found south of the Rand Mountains and $9 \mathrm{~km}$ southwest of Galileo Hill suggest southwest-flowing streams that crossed the granite pediment during the late Pliocene(?) and early Pleistocene (figs. 6, 7, 8). The polymict clast assemblage includes several types of coarsely crystalline pink granite and potassium feldspar-rich red granite, lithic tuff and felsite, andesite, rhyolite, and some basalt. The deposits are generally well cemented with pedogenic carbonate and may have a preserved laminar cap. The soil carbonate has been brecciated and is crosscut by calcite-filled dikes (Stage IV to VI pedogenic carbonate morphology, Machette, 1985).

In several locations, these polymictic extremely old alluvial gravel deposits unconformably overlie granodiorite bedrock as channels cut into the bedrock (fig. 7), suggesting that these extremely old gravels were probably transported over the pediment. Locally derived granodiorite clasts are found in these deposits. The clast types are similar to those of conglomerates in the Goler Formation and upper Dove Spring Formation and may be reworked from these deposits.

A deposit of unit QToa deposits and old alluvial deposits (unit Qoa) that lies northeast of Calif. Hwy 14 forms sinuous ridges whose tops parallel a small drainage that empties into Red Rock Canyon (southeast of the abandoned town of Ricardo). Subangular to subrounded gravel as large as cobbles and composed of granite, quartzite, andesite, and basalt within a grus matrix unconformably overlie middle Dove Spring Formation. No imbrication or other indicators of flow direction were observed. 


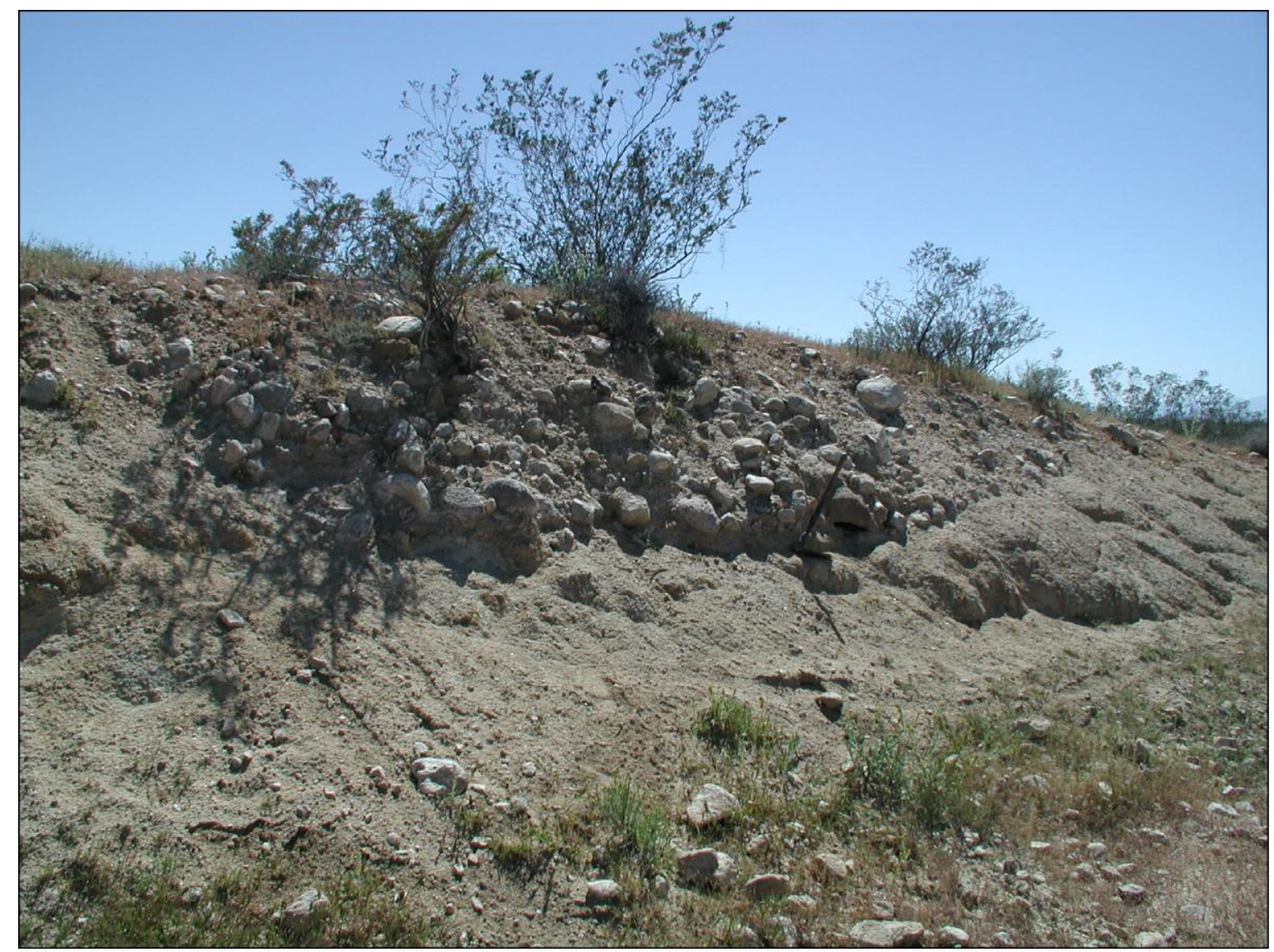

Figure 7. Roadcut showing a channel filled with polymict QToa gravel that is cut into granodiorite. Clasts mainly derived from granitic rocks, but also from rhyolite and felsic tuffs; basalt and andesite clasts are rare. Channel strikes S. $30^{\circ}$ W. Shovel handle is $50 \mathrm{~cm}$ long.

\section{Pediments and Pediment Formation}

Pediments are nearly flat erosional surfaces in various stages of bedrock degradation, exposure, and burial. They are formed on granite and granodiorite bedrock in the east-central, south-central, and western parts of the Cuddeback Lake quadrangle. The pediments, whether incised, deeply dissected, or characterized by a veneer of alluvium or weathering products, surround many of the hills and mountains underlain by plutonic rocks. Pediments have been hypothesized to form by the downwearing of deep (Tertiary?) weathered materials (Dohrenwend and others, 1986), the backwasting of regolith-covered slopes (Oberlander, 1989), or parallel slope retreat from a bounding fault (Cooke and Warren, 1973).

Observations supporting the downwearing model are seen in the residual hills of granite capped by polymict unit QToa deposits (fig. 9). These alluvial deposits, which likely represent late Tertiary to early Quaternary river deposits, are now as much as $30 \mathrm{~m}$ above the modern drainages. Another location, $10 \mathrm{~km}$ southeast of Castle Butte, shows about $10 \mathrm{~m}$ of pediment downwearing between the contact elevation at the base of small basalt hills overlying granite and the modern valley-floor elevation.

Pediment development on the southern part of the west half of the Rand Mountains appears to be tectonically controlled, by either uplift of the mountain block or downdrop of the Fremont Valley. The pediment has a thin veneer, though northwest of Galileo Hill it appears to be buried by young grussy alluvium. Pediment development likely predates tectonic displacement, because the present pediment surface ends abruptly at the mountain crest. The Mabey (1960) gravity map does 


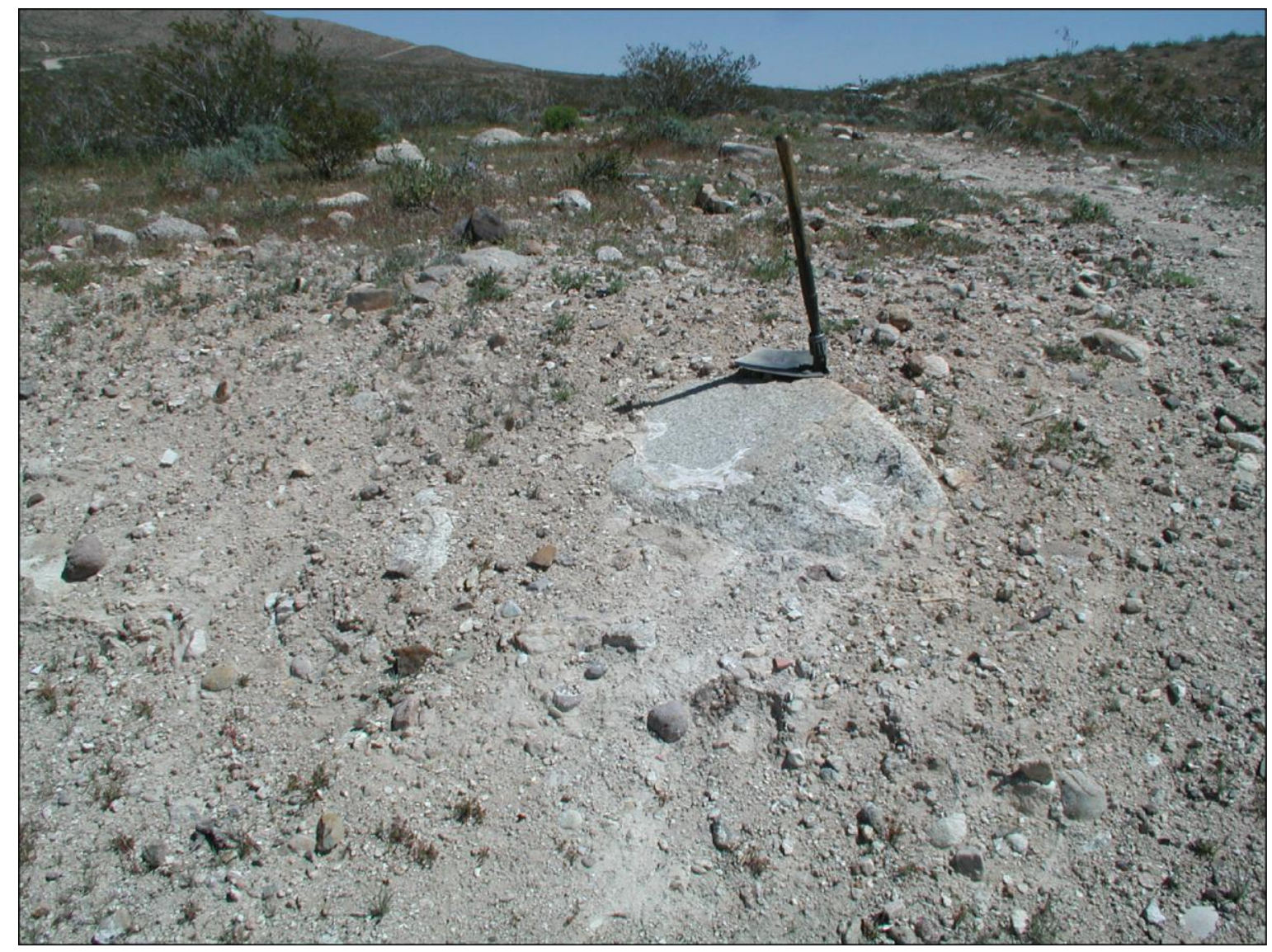

Figure 8. Roadcut exposure of unit QToa. Clasts are coated by pedogenic carbonate. Note the 60-cmdiameter boulder below the shovel. Clasts this size suggest vigorous stream flow. Imbrication measurements here indicated the stream flowed N. $62^{\circ} \mathrm{W}$. Shovel handle is $50 \mathrm{~cm}$ long.

not show evidence of a bounding fault along the south flank of the Rand Mountains. It appears that the pediment was terminated during the creation of the deep basin beneath Fremont Valley due to movement on the Garlock Fault. Based on age estimates of initial movement on the Garlock Fault, pedimentation may have begun in the western Mojave Desert before early to middle Miocene time (Louie and Qin, 1991; Monastero and others, 1997; Smith and others, 2002).

Escarpment backwasting is seen along the Muroc Fault, where the topographic crest has retreated approximately $475 \mathrm{~m}$ from the fault trace (fig. 10). Smaller amounts of scarp retreat are seen along small fault splays of the Muroc Fault (fig. 11). Backwasting also occurred where strands of the Lockhart Fault and southern Lockhart Fault cut across granitic pediments. Where there is a dip-slip component of movement, the local topographic crest has retreated from the fault trace.

\section{Development and Age of Pediment Veneers}

The relation of soil developed on weathered bedrock and alluvium to pediment development in the Mojave Desert has been studied by several investigators (Boettinger and Southard, 1991, 1995; Cooke and Mason, 1973; Eghbal and Southard, 1993a,b). Because weathered bedrock and saprolite are generally found beneath the alluvial veneer on the pediment, it appears that some of the middle to late Pleistocene alluvial veneer is developed from locally derived saprolite. That is, the weathering of the in-place bedrock precedes alluviation and the development of soil, an idea proposed by Cooke and Mason (1973). They also asserted that there was "no consistent or distinctive relationship between the soil profile and the extent of bedrock 


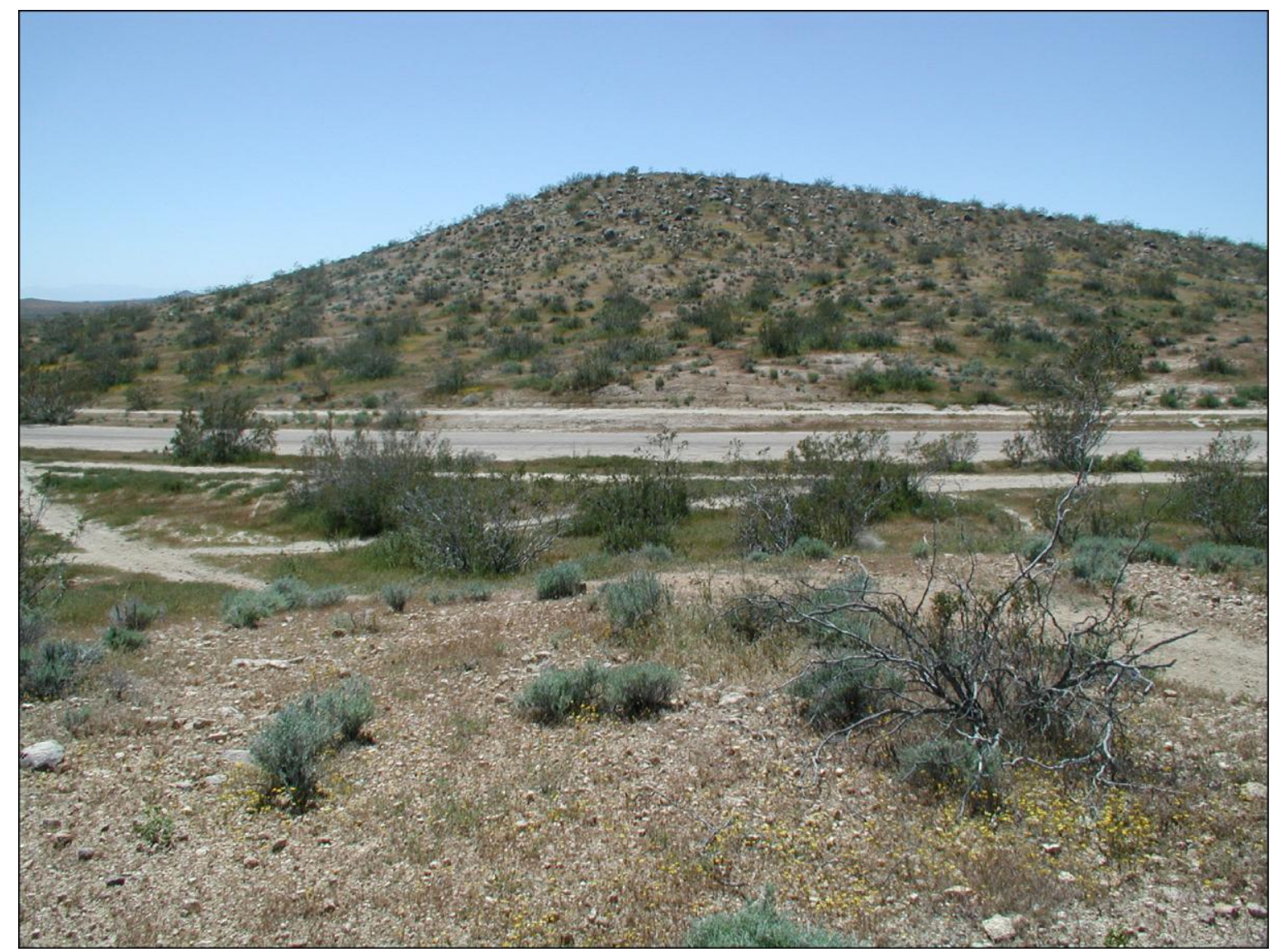

Figure 9. View southwest of small hill ( $\sim 30 \mathrm{~m}$ high) underlain by granodiorite and capped by unit QToa gravels. The roadcut exposure of figure 8 is just to the right of this photograph. In the foreground, a granodiorite pediment is covered with coarse-grained grus but no QToa gravel. Topographic inversion has occurred during downwearing of the pediment since the early Pleistocene to Pliocene.

weathering," that is, that the soil formation and bedrock weathering occurred separately. Based on the Boettinger and Southard (1991) work and field observations, the granite saprolite could be the parent material for much of the early to late Pleistocene alluvium composed of grus (units Qoag and Qiag) that lies on granitic pediments in the Cuddeback Lake quadrangle (fig. 12).

Evidence observed in many places on the pediment that supports granite saprolite as the parent material includes preservation of rock fabric, clay chemistry consistent with weathering of the parent material (Boettinger and Southard, 1991), and translocation of soluble minerals and silica deeper within the matrix. In contrast, in some places the lack of bedrock fabric, the presence of illuviated materials (clay, silt, and carbonate), and the presence of horizontal stratification suggests that soils are being formed in alluvium derived from the eroding of bedrock and saprolite. This latter relation is particularly common in unit Qiag and unit Qoag deposits located southwest of Fremont Peak and west of The Buttes. The age of these deposits is not well constrained. Eghbal and Southard (1993a,b) studied the micromorphology and stratigraphy of soils formed in granitic alluvium northeast of California City, which was probably derived from erosion of the pediment on the south side of the Rand Mountains. The soils developed in unit Qiag appear to be developed in reworked, very old alluvium that is more than $783 \mathrm{ka}$ because the deeper part of the deposit $(>2 \mathrm{~m})$ has a reversed paleomagnetic polarity (Eghbal and Southard, 1993a). This suggests that the old alluvial deposit composed of grus (Qoag) is older than middle Pleistocene. 


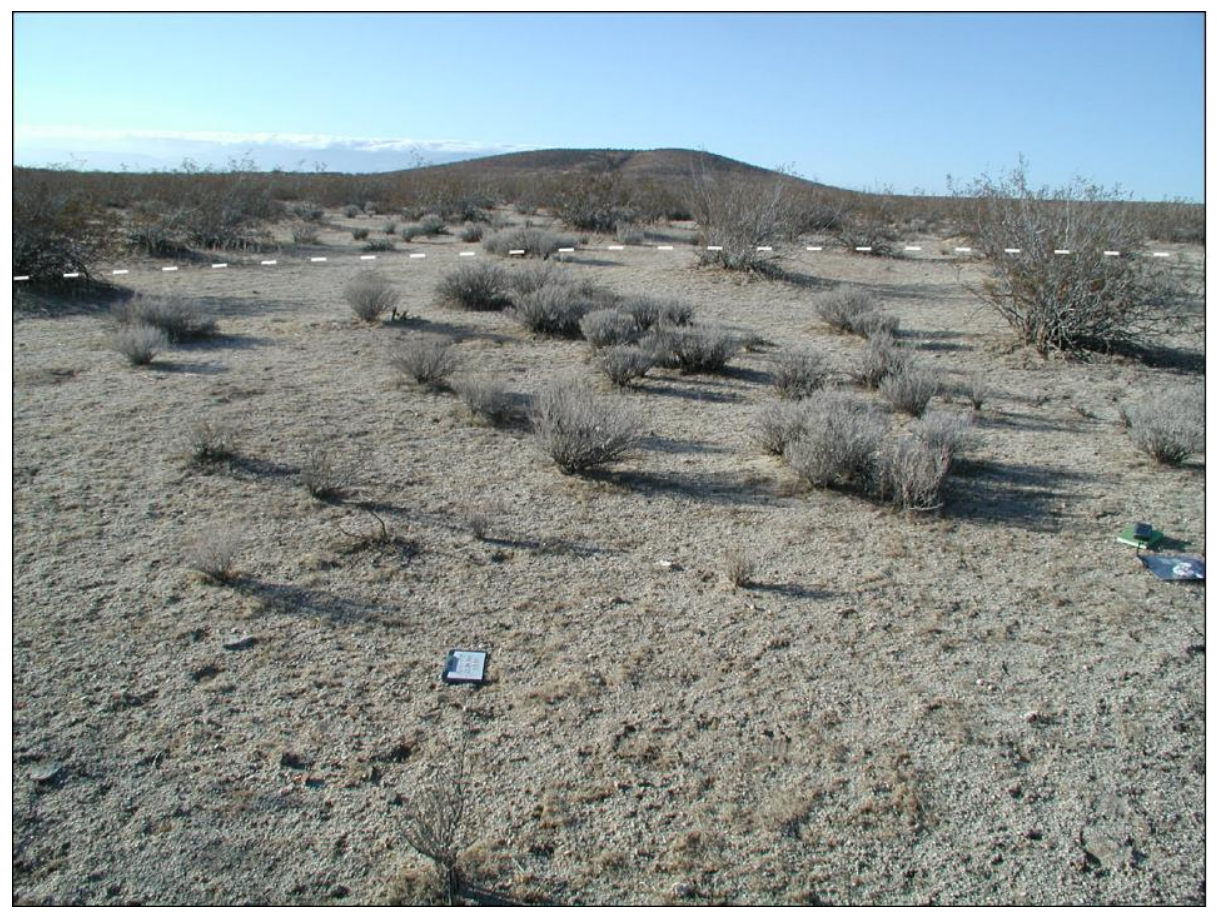

Figure 10. View northwest of a subtle expression of the Muroc Fault (approximately located by white line) and degraded scarp in the middle distance. The Holocene and late Pleistocene-age surface materials are composed of grus derived from the granodiorite bedrock; the low cohesiveness of grus means the fault scarps are probably poorly preserved. The granodiorite knob in the distance may be the result of scarp retreat.

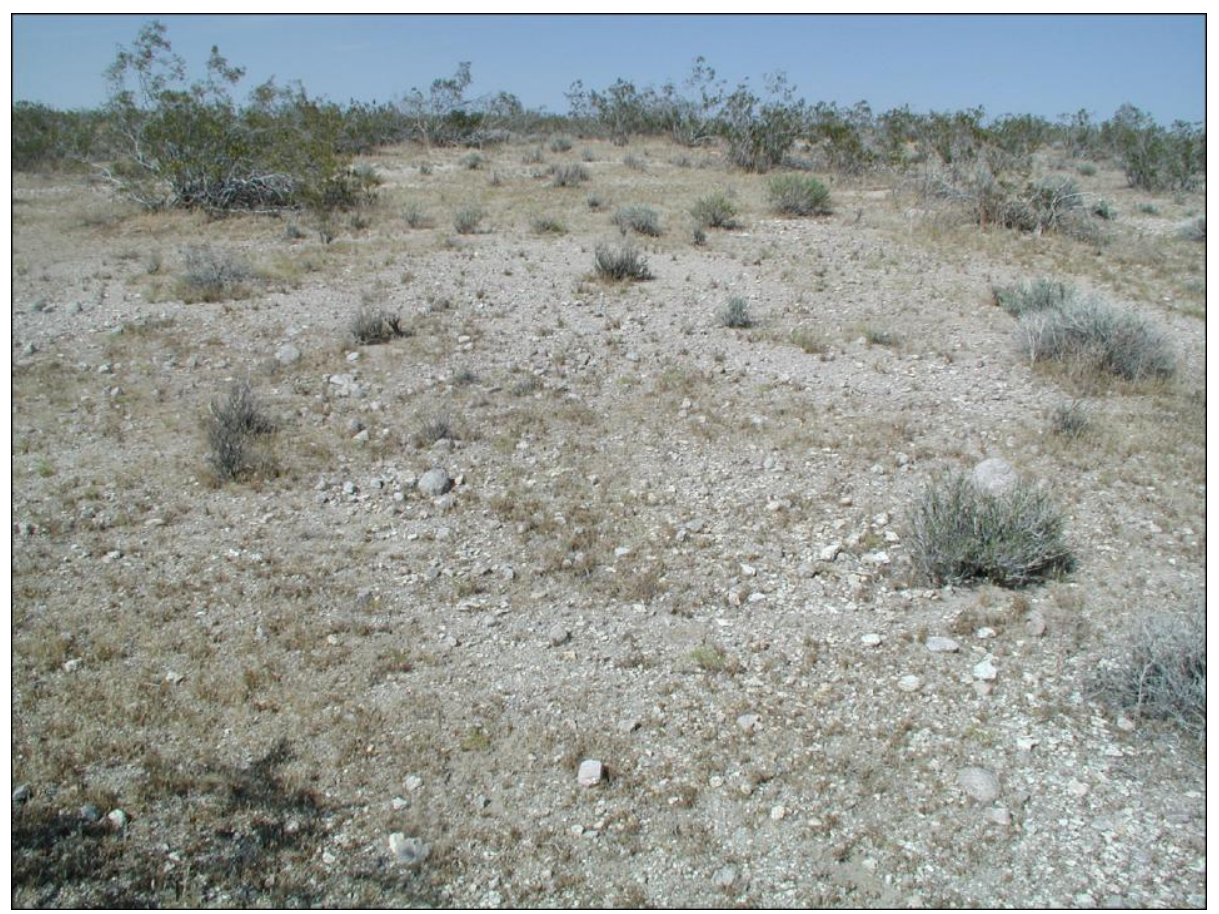

Figure 11. View northwest of carbonate debris exposed during retreat from the Muroc Fault scarp. The carbonate debris is presumed to be eroded from the upthrown side during scarp retreat. The debris creates linear features that are easily seen on aerial photographs. The fault trace is about $70 \mathrm{~m}$ behind the photograph point. 


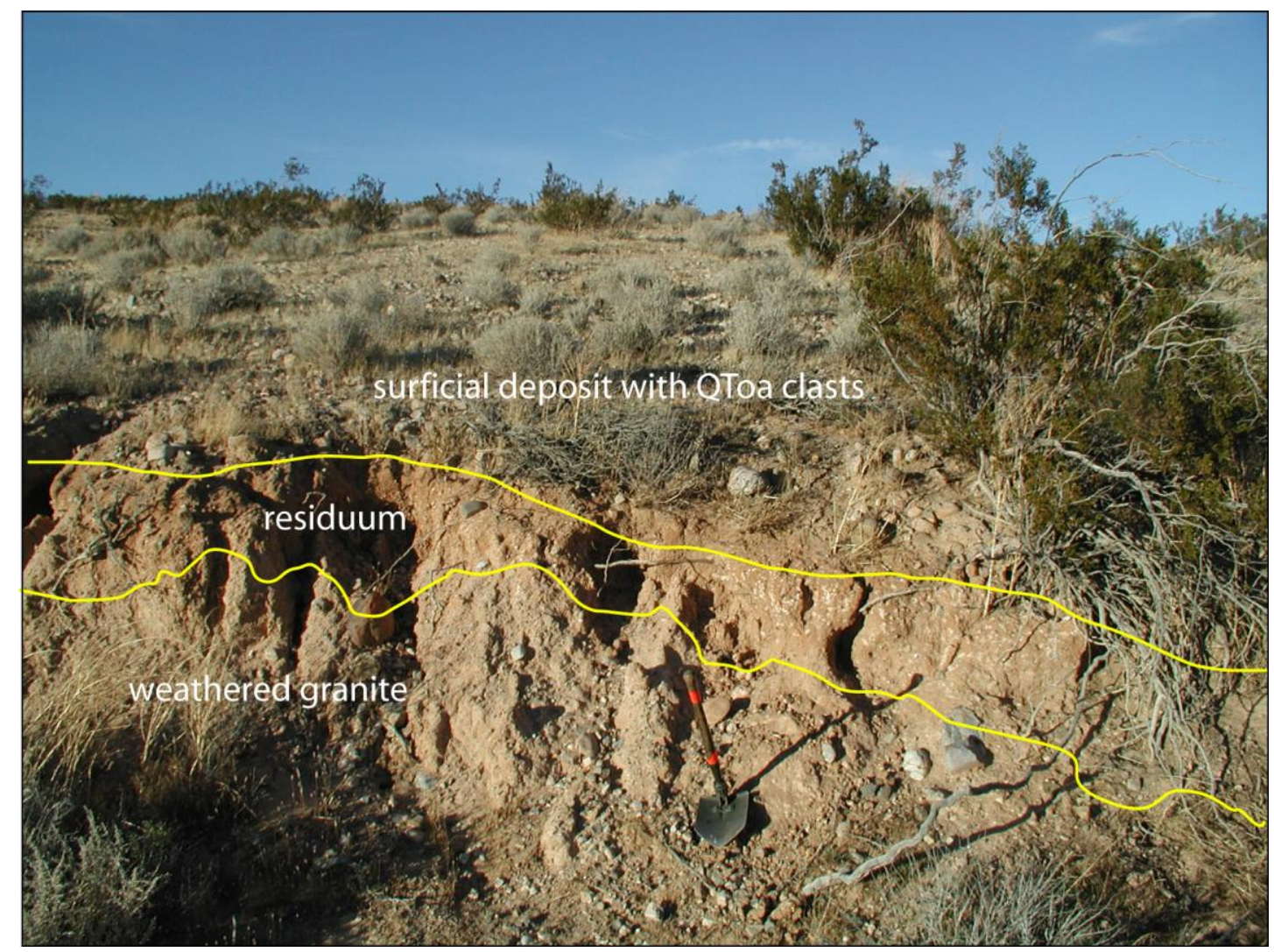

Figure 12. Photograph showing residuum developed on weathered granite slope. Evidence of the original rock fabric appears faintly preserved in the residuum. Carbonate blebs $(1-2 \mathrm{~cm})$ are developed in the clay-rich residuum. Note that clasts from QToa deposits rest on or are incorporated into the young to intermediate-age surficial deposit (Qyag or Qiag) overlying the residuum. Nearby, the QToa deposit rests directly on the granite. The pedimentation and residuum development predates deposition of the estimated early Pleistocene to late Tertiary alluvium (QToa). Qoag alluvium is found downslope from this location and may be derived from stripping of the residuum. Shovel handle is $50 \mathrm{~cm}$ long. Photograph location $4 \mathrm{~km}$ south of the southern Cuddeback quadrangle boundary.

\section{Acknowledgments}

This surficial geologic map is a product of the Surficial Geology Project, funded by the National Cooperative Geologic Mapping and Earth Surface Dynamics Programs, U.S. Geological Survey. Reviews by George Billingsley, Phil Stoffer, and Charles L. Powell, II, are appreciated for the improvements they brought to the map and map unit descriptions. Scott Graham reviewed the geodatabase and J.L. Zigler edited the manuscript, both making significant improvements. We appreciate discussions with Mike Oskin, Bob Reynolds, and Brett Cox that helped us to understand several aspects of active tectonics and regional geology. 


\section{DESCRIPTION OF MAP UNITS}

\section{DEPOSITIONAL LANDSCAPE}

\section{ANTHROPOGENIC DEPOSITS}

$\mathrm{ml} \quad$ Made land or artificial fill (latest Holocene) - Surficial material moved for mining, construction, and agriculture that is extensively disturbed, making landforms and deposits difficult to classify

pf Ponded fill (latest Holocene) — Sand and silt deposits that are active and have received material in the last few decades as the result of damming of drainages by man-made features such as roads, railroad beds, and flood control barriers. Similar to active playa deposit (Qap). Commonly vegetated with creosote bush (Larrea tridentata) and saltbush (Atriplex sp.)

\section{VALLEY-AXIS DEPOSITS}

Qav Active valley-axis deposit (latest Holocene) — Loose, fine-grained deposits in valley axes characterized by anastomosing ephemeral washes, low-relief interfluves, and eolian deposits. Small active playa deposits may be associated with these deposits. Prone to inundation and flooding during and after heavy rains. Moderately vegetated with various perennial shrubs such as desert senna (Senna armata), creosote bush (Larrea tridentata), white bursage (Ambrosia dumosa), and saltbush (Atriplex sp.)

Qyv Young valley-axis deposit (Holocene and latest Pleistocene)—Deposits of sand and fine gravel in valley axis characterized by inactive anastomosing ephemeral washes, low-relief interfluves, and eolian deposits. These deposits grade into the distal portions of young alluvial fan deposits (Qya). Soil formation is similar to Qya. Small, young playa deposits may be associated with these deposits. Prone to flooding during heavy rains. Moderately vegetated with creosote bush (Larrea tridentata), white bursage (Ambrosia dumosa), and several species of saltbush (Atriplex sp.)

\section{WASH DEPOSITS}

Qaw Active wash deposit (latest Holocene) - Alluvial wash deposits characterized by surfaces and channels that are active and have received deposits within the last few decades. Moderately to poorly sorted sand, sandy gravel, and clasts to $80 \mathrm{~cm}$ in diameter. Coarser grained near mountain fronts or where washes cross boulder- to cobble-bearing parent materials. Poorly to moderately bedded and loose. Channel bars as high as $50 \mathrm{~cm}$. Smaller alluvial-wash tracts are generally included in active alluvial fan deposits (unit Qaa). Shows little to no soil development. Sparsely vegetated with perennial shrubs such as desert senna (Senna armata), creosote bush (Larrea tridentata), and white bursage (Ambrosia dumosa), as well as annuals. Prone to channelized flow and flooding 
during and after heavy rains. Active on a decadal time scale based on burial of or damage to late 20th century trails, roads, and structures

Qawg Active wash deposit composed primarily of grus (latest Holocene) -

Alluvial wash deposits characterized by surfaces and channels that are active and have received deposits within the last few decades.

Moderately to poorly sorted sand and fine gravel

Qyw Young wash deposit (Holocene and latest Pleistocene) - Moderately to poorly sorted sand and silt, sandy gravel, and clasts to $50 \mathrm{~cm}$ in diameter.

Coarser grained near mountain fronts and steep alluvial fans or where washes cross boulder- to cobble-bearing parent materials. Poorly to moderately bedded; loose to poorly consolidated. Channel bars as high as $50 \mathrm{~cm}$. Smaller alluvial wash tracts are generally designated as young alluvial fan deposits (Qya). Younger deposits show no soil development; older deposits show weak, incipient Av horizon and weak B horizon development (similar to older young alluvial fan deposits, Qya).

Sparsely to moderately vegetated with perennial shrubs including desert senna (Senna armata), creosote bush (Larrea tridentata), white bursage (Ambrosia dumosa), and several species of saltbush (Atriplex sp.). Prone to channelized flow and flooding during and after heavy rains. Active on a centennial time scale based on burial of late 19th and early 20th century trails and structures

Qiw Intermediate-age wash deposit (late to middle Pleistocene)-Parent material is moderately to poorly sorted sand and silt, sandy gravel, and clasts to $40 \mathrm{~cm}$ in diameter. Deposits are coarser grained near mountain fronts and may be as much as $5 \mathrm{~m}$ ( $8 \mathrm{~m}$ near active faults) above the active channel. Poorly to moderately bedded; poorly to moderately consolidated. Channel bars as high as $10 \mathrm{~cm}$. Shows moderate to strong soil development, well-developed platy to blocky Av horizons as thick as 7 $\mathrm{cm}$, and moderate cambic B (7.5 to 5 YR hue) horizon development. Older deposits have argillic Bt (to 2.5 YR hue) with angular, prismatic peds and may have surface litter from fragments of exhumed calcic horizons. Some middle to late Pleistocene soils show Stage II to III+ pedogenic carbonate morphology. (See Gile and others, 1981 for a description of pedogenic carbonate morphology.) Sparsely to moderately vegetated with perennial shrubs such as creosote bush (Larrea tridentata), white bursage (Ambrosia dumosa), and boxthorn (Lycium sp.). Prone to channelized flow and flooding during and after heavy rains

\section{ALLUVIAL AND DEBRIS-FLOW DEPOSITS}

Qaa Active alluvial fan deposit (latest Holocene) - Alluvial fan deposits characterized by surfaces that are active and have received deposits within the last few decades. Moderately to poorly sorted sand and sandy gravel, with clasts to $25 \mathrm{~cm}$ in diameter. Little or no soil development. Coarser texture near mountain fronts or older coarse-grained deposits that are being reworked; average grain size decreases downslope. Poorly to moderately bedded and loose with channel bars as high as $30 \mathrm{~cm}$. Inset into young alluvial fan deposits (Qya). Sparsely vegetated with perennial 
shrubs such as desert senna (Senna armata), creosote bush (Larrea tridentata), white bursage (Ambrosia dumosa), and saltbush (Atriplex sp.). Prone to inundation and flooding during and after heavy rains Active alluvial fan deposit composed of grus (latest Holocene) Composed of moderately to poorly sorted sand and fine gravel derived from grus-producing granite sources but may contain clasts from other lithologic sources. Surfaces have received deposits within the last few decades. Poorly bedded to massive; loose to very weakly consolidated. Shows no soil development. Unit moderately to well vegetated with various perennial shrubs such as creosote bush (Larrea tridentata), white bursage (Ambrosia dumosa), and desert senna (Senna armata). Surface may be flooded during and after heavy rains. Drainage patterns are simple; some have low relief that may be related to grain size poorly sorted sand and silt, sandy gravel, and clasts to $85 \mathrm{~cm}$ in diameter. Characterized by abandoned surfaces that receive material infrequently. Poorly bedded to massive; loose to poorly consolidated. Bar and swale microtopography averages $25 \mathrm{~cm}$ in height and decreases downfan. Surfaces lie 10-50 cm (as much as $300 \mathrm{~cm}$ near active faults) above active channels. Shows little or no soil development. Moderately to well vegetated with perennial shrubs such as desert senna (Senna armata), creosote bush (Larrea tridentata), white bursage (Ambrosia dumosa), and several saltbush (Atriplex sp.) species. Surface may be flooded (as deep as $25 \mathrm{~cm}$ based on flotsam evidence) during and after heavy rains. Active on a centennial time scale based on burial of late 19th and early 20th century trails and structures

Young alluvial fan deposit composed of grus (Holocene and latest Pleistocene) - Moderately to poorly sorted sand and fine gravel derived from grus-producing granite sources but may contain clasts from other lithologic sources. Characterized by abandoned surfaces that receive material infrequently. Poorly bedded to massive; loose to very weakly consolidated. Bar and swale microtopography generally subdued but may be as high as $20-40 \mathrm{~cm}$ near mountain fronts. Surfaces lie $10-30 \mathrm{~cm}$ above active channels and may be inset into intermediate-age alluvial fan deposits composed of grus (Qiag). Shows little or no soil development. Moderately to well vegetated with perennial shrubs such as creosote bush (Larrea tridentata), white bursage (Ambrosia dumosa), and several species of saltbush (Atriplex sp.). Surface may be flooded during and after heavy rains. Drainage patterns are simple with low relief and may be related to grain size

Qia Intermediate-age alluvial fan deposit (late and middle Pleistocene) Moderately to poorly sorted sand and silt, sandy gravel, and clasts to 130 $\mathrm{cm}$ in diameter. Characterized by surfaces that have been abandoned for tens to hundreds of thousands of years. Poorly bedded to massive; weakly to moderately consolidated. Bar and swale microtopography is subdued to $10 \mathrm{~cm}$ in height, though the surface is generally flat and incised by shallow channels. Surfaces generally $250 \mathrm{~cm}$ above active 
channels and inset into old alluvial fan deposits (Qoa). Moderate to strong soil development, well-developed platy to blocky Av horizons as thick as $8 \mathrm{~cm}$, and moderate cambic B horizon development (7.5 to $5 \mathrm{YR}$ hue). Older deposits in this unit have argillic Bt (to 2.5 YR hue) with angular, prismatic peds or may have surface fragments from exhumed calcic horizons. Some middle to late Pleistocene soils have Stage II to III+ pedogenic carbonate morphology. Sparsely to moderately vegetated with perennial shrubs such as creosote bush (Larrea tridentata), white bursage (Ambrosia dumosa), and boxthorn (Lycium sp.). Rhatany (Krameria grayi) appears to prefer carbonate-rich soils. Surface is rarely flooded during and after heavy rains Pleistocene) - Parent material is moderately to poorly sorted fine gravel, sand, and silt primarily derived from grus-producing granite but may contain clasts from other lithologic sources. Characterized by surfaces abandoned for tens to hundreds of thousands of years. Poorly bedded to massive; moderately consolidated. Bar and swale microtopography usually subdued. Surfaces lay an average of $160 \mathrm{~cm}$ (up to $5 \mathrm{~m}$ near active faults) above active channels and may be inset into old alluvial fan deposit composed of grus (Qoag). Shows moderate to strong soil development: absent to moderately developed Av horizons; moderate cambic B horizon development (7.5 to 5 YR hue). Soils range to argillic Bt (to 2.5 YR hue) with angular, prismatic peds. Some soils have Stage II to III+ pedogenic carbonate morphology; carbonate accumulations are found at the alluvium/bedrock interface. Sparsely to moderately vegetated with perennial shrubs such as creosote bush (Larrea tridentata), white bursage (Ambrosia dumosa), boxthorn (Lycium sp.), and saltbush (Atriplex sp.). Surface is rarely flooded during and after heavy rains

Intermediate-age alluvial fan composed of debris-flow deposits (late to middle Pleistocene) — Deposits similar to those for unit Qia, but containing $>50 \%$ materials deposited by debris flows. These deposits possess distinctive hummocky topography

Qoa Old alluvial fan deposit (middle to early Pleistocene) - Parent material is moderately to poorly sorted sand and sandy gravel, with clasts as large as $110 \mathrm{~cm}$ in diameter. Characterized by deeply incised fan remnants that have been abandoned for hundreds of thousands of years. Many surfaces have been stripped to a well-indurated soil carbonate or are littered with carbonate debris. Poorly bedded to massive; well consolidated. Surfaces lay an average of $850 \mathrm{~cm}$ (up to $20 \mathrm{~m}$ near active faults) above active channels and may be inset into late Tertiary units. Strong soil development: Stage IV and greater carbonate morphology. Younger deposits with Av and cambic B horizon may be developed unconformably on the stripped Qoa deposit. Unit is sparsely to moderately vegetated with perennial shrubs such as creosote bush (Larrea tridentata), white bursage (Ambrosia dumosa), and boxthorn 
(Lycium sp.). Rhatany (Krameria grayi) appears to prefer carbonate-rich soils. Surface is rarely flooded during and after heavy rains

Pleistocene) - Moderately to poorly sorted sand and silt derived from grus-producing granite sources but may contain clasts from other lithologic sources. Characterized by deeply incised fan remnants that have been abandoned for hundreds of thousands of years. Some parts of unit may result from localized reworking of materials derived from a deeply weathered pediment. Many surfaces stripped to the wellindurated soil carbonate or are littered with carbonate debris. Poorly bedded to massive; well consolidated. Surfaces lay an average of $850 \mathrm{~cm}$ (up to $20 \mathrm{~m}$ near active faults) above active channels. Strong soil development: Stage IV and greater carbonate morphology; carbonate accumulations are found at the alluvium/bedrock interface; in places, surface veneers similar to unit Qiag. Sparsely to moderately vegetated with perennial shrubs such as creosote bush (Larrea tridentata), white bursage (Ambrosia dumosa), and boxthorn (Lycium sp.), which appears to prefer carbonate-rich soils. Surface is rarely flooded during and after heavy rains

QToa Extremely old alluvial fan deposit (early Pleistocene to Pliocene) - Alluvial fan deposits characterized by the degraded remnants of abandoned surfaces. Moderately to poorly sorted sand and sandy gravel with clasts to $400 \mathrm{~cm}$ in diameter. Clasts predominantly composed of mafic volcanic rocks in deposits north and east of the Rand Mountains. Clasts predominantly composed of mixed lithology including several types of granite, quartzite, tuff, glassy rhyolite, and minor andesite and basalt in deposits south and west of the Rand Mountains. Polymictic QToa deposits are similar to lower Cudahy Camp Formation conglomerate, which in turn are suggested to be reworked Goler Formation (Loomis and Burbank, 1988). Deposits west of Galileo Hill show imbrication implying transport to the southwest. Some deposits lie in paleochannels cut into the granite pediment. Equivalent to the Christmas Canyon Formation mapped in the Lava Mountains area by Smith (2009). Surfaces characterized by deeply incised remnants that have been abandoned for many hundreds of thousands of years; range from rounded remnants to planar landforms as much as $50 \mathrm{~m}$ above the modern drainages. Commonly stripped to a well-indurated soil carbonate or are littered with carbonate debris. Weakly developed soils formed on veneers of eolian and alluvial material. Poorly bedded to massive; well consolidated. Sparsely to moderately vegetated with perennial shrubs such as white bursage (Ambrosia dumosa) and boxthorn (Lycium sp.). Creosote bush (Larrea tridentata) generally a minor component. Desert trumpet (Eriogonum inflatum) abounds on the high planar deposits. Surface is rarely flooded during and after heavy rains 


\section{EOLIAN DEPOSITS}

Qae

Qaed

Qaes

Qaer

Qye

Qyed

Qyes

Qyer

Qaae

Qaea

Qyae

Qyea

Qiae
Active eolian deposit (latest Holocene) — Eolian sand deposits that are active and show evidence of migration. Composed of moderately sorted to well-sorted sand and silt; loose; little or no soil development. Sparsely vegetated with perennial shrubs such as Joshua tree (Yucca brevifolia), creosote bush (Larrea tridentata), white bursage (Ambrosia dumosa), and saltbush (Atriplex sp.). Subdivided based on geomorphology:

Active eolian sand dune deposit (latest Holocene)—Eolian sand deposits forming dunes

Active eolian sand sheet deposit (latest Holocene)—Eolian sand deposits forming featureless broad sheets

Active eolian sand ramp deposit (latest Holocene) — Eolian sand deposits forming ramps of climbing and falling dunes, typically mantling bedrock

Young eolian deposit (Holocene and latest Pleistocene) - Eolian sand deposits that are generally inactive. Composed of moderately sorted to wellsorted sand and silt; loose. Little or no soil development but may show significant soil carbonate accumulation downwind of playas and dry lakes. Sparsely vegetated with perennial shrubs such as Joshua tree (Yucca brevifolia), creosote bush (Larrea tridentata), prickly pear (Opuntia erinacea), cholla (Opuntia parishii, Opuntia acanthocarpa), and saltbush (Atriplex sp.). Subdivided based on geomorphology:

Young eolian sand dune deposit (Holocene and latest Pleistocene) Eolian sand deposits that form dunes

Young eolian sand sheet deposit (Holocene and latest Pleistocene) Eolian sand deposits forming featureless broad sheets

Young eolian sand ramp deposit (Holocene and latest Pleistocene) Eolian sand deposits forming ramps of climbing and falling dunes, typically mantling bedrock

\section{MIXED ALLUVIAL AND EOLIAN DEPOSITS}

Active mixed alluvial and eolian deposit (latest Holocene)—Mixed alluvial and eolian deposits that show evidence of migration. Alluvial deposits predominate

Active mixed eolian and alluvial deposit (latest Holocene) - Mixed eolian and alluvial materials that show evidence of migration. Eolian deposits predominate

Young mixed alluvial and eolian deposit (Holocene and latest Pleistocene) Mixed alluvial and eolian deposits that are generally inactive. Alluvial deposits predominate

Young mixed eolian and alluvial deposit (Holocene and latest Pleistocene) Mixed eolian and alluvial deposits that are generally inactive. Eolian deposits predominate

Intermediate-age mixed alluvial and eolian deposit (late to middle Pleistocene)_Alluvial deposits predominate. Surfaces generally flatter than respective age alluvial fan deposits; poor to moderate desert pavement development. Sand and gravelly sand displaying indistinct to 
well-defined thin bedding. Soil development is variable with weak to moderate cambic $\mathrm{B}$ horizons to weak argillic $\mathrm{Bt}$ horizons

Pleistocene) - Eolian deposits predominate. Forms flat to gently crowned surfaces. Soil development is variable with weak to moderate cambic B horizons to weak argillic Bt horizons

\section{PLAYA DEPOSITS}

Qap Active playa deposit (Holocene) - Playa deposits that have been flooded and have received sediment in the last few decades. Composed of fine sand, silt, and clay; salts may be present as efflorescences or as weak cements. Surfaces are flat and prone to flooding; surface water may pond on these low-permeability materials. Sparsely vegetated to barren. Plants such as iodine bush (Allenrolfea occidentalis), four-wing saltbush (Atriplex canescens), shadscale (Atriplex confertifolia), and hopsage (Grayia spinosa) fringe the playa

Qaps Active playa sandy facies deposit (Holocene)_Playa deposits that contain layers of sand. Typically found near margins of playa

Qapf Active playa fringe deposit (Holocene) - Active playa fringe that has received sediment in the last few decades. Generally flat, rolling, or hummocky topography, barren to sparsely vegetated, and containing a mix of eolian, alluvial, lacustrine, groundwater discharge, and playa deposits

Qyp Young playa deposit (Holocene and latest Pleistocene) - Playa deposits that are rarely flooded because they lie above the center of the basin; may have received sediment during the last few centuries or may be undergoing erosion. Composed of fine sand, silt, and clay. Weakly to moderately indurated; may show weak cambic B horizon development. Surfaces are very gentle slope and prone to flooding during heavy rains. Sparsely vegetated to barren. Plants such as iodine bush (Allenrolfea occidentalis), four-wing saltbush (Atriplex canescens), shadscale (Atriplex confertifolia), and hopsage (Grayia spinosa) are scattered along drainage channels

Qyps Young playa sandy facies deposit (Holocene and latest Pleistocene)Sandy playa deposits that are generally inactive

Young playa fringe deposit (Holocene and latest Pleistocene) - Lowrelief, barren to poorly vegetated, complex deposits with small dunes, shoreline deposits, and alluvial fan deposits interspersed with playas. Common near young ephemeral stream channels (Qyw)

\section{LACUSTRINE DEPOSITS}

Qil Intermediate-age lacustrine deposit (late to middle Pleistocene) - Complexly varying deposits of fine sand, silt, and clay; thin bedded to massive. Represents nearshore lake deposits and distal alluvial fan deposits modified by wave action. Soil development is similar to intermediate-age alluvial fan deposits (Qia). Differs from distal alluvial fan deposits by containing very well sorted, thin-bedded sand and silt. Sparsely 
vegetated to barren. Plants include four-wing saltbush (Atriplex canescens), shadscale (Atriplex confertifolia), and hopsage (Grayia spinosa)

Qilg

Qils

Qigw

Qygw

Qmc

Qyml

Qiml

QTml

Intermediate-age lacustrine gravel deposit (late to middle Pleistocene) Deposits of well-sorted, bedded gravel generally associated with beach and barrier bar landforms. Best developed east of Harper and Koehn Lakes

Intermediate-age lacustrine sand deposit (late to middle Pleistocene) Well-sorted fine, very fine, and medium grained sand forming thinbedded low-relief platforms. Sparsely vegetated. Plants include fourwing saltbush (Atriplex canescens), shadscale (Atriplex confertifolia), and hopsage (Grayia spinosa)

\section{GROUNDWATER-DISCHARGE DEPOSITS}

Young groundwater wetland deposit (Holocene and latest Pleistocene) Indistinctly bedded silt with fine sand and clay, typically pale colored due to extensive calcium carbonate in matrix. Forms platforms and badlands upslope from low points in broad valleys, at sites of marshes caused by former groundwater discharge. Sparsely vegetated. Plants include four-wing saltbush (Atriplex canescens), shadscale (Atriplex confertifolia), and hopsage (Grayia spinosa)

\section{Intermediate-age groundwater wetland deposit (late to middle}

Pleistocene) - Indistinctly bedded silt with fine sand and clay, typically pale colored due to extensive calcium carbonate in matrix. Forms deeply eroded small hills in zones of former groundwater discharge. May overlie or intercalate with intermediate-age and old alluvial deposits (Qia, Qoa, Qiag, Qoag). Sparsely vegetated. Plants include four-wing saltbush (Atriplex canescens), shadscale (Atriplex confertifolia), and hopsage (Grayia spinosa) with minor creosote bush (Larrea tridentata) and white bursage (Ambrosia dumosa)

\section{EROSIONAL LANDSCAPE}

\section{COLLUVIAL AND LANDSLIDE DEPOSITS}

\section{Mass-movement colluvial deposits (Holocene and Pleistocene)-Hillslope} materials thicker than $2 \mathrm{~m}$ and covering a wide area. Sparsely vegetated

\section{Young mass-movement landslide deposit (Holocene and latest}

Pleistocene) - Landslide deposits, thicker than $2 \mathrm{~m}$, that cover a wide area

\section{Intermediate-age mass-movement landslide deposit (Pleistocene) -}

Landslide deposits, thicker than $2 \mathrm{~m}$, that cover a wide area. Deposit

typically exhibits desert pavement and strongly developed desert varnish. Present in the northwestern map area

\section{Extremely old mass-movement landslide deposit (early Pleistocene to}

Pliocene)-Landslide deposit, thicker than $2 \mathrm{~m}$, cemented with massive pedogenic carbonate. Present north of Koehn Lake 


\section{HILLSLOPE DEPOSITS}

Qha Abundant hillslope deposits (Holocene and Pleistocene)-Hillslope materials, such as colluvium, talus, and weathering products, cover $>50 \%$ of the rock surface. Generally $<2 \mathrm{~m}$ thick or patchy distribution

Qhs Sparse hillslope deposits (Holocene and Pleistocene)-Hillslope materials, such as colluvium, talus, and weathering products, cover $<50 \%$ of the rock surface. Generally $<2 \mathrm{~m}$ thick or patchy distribution

\section{PEDIMENT SURFACES}

Erosional surfaces in various stages of erosion or aggradation. Divided into three classes by surface characteristics

Qpv Veneered pediment (Holocene and Pleistocene) - Veneer of sediment, generally $<2 \mathrm{~m}$ thick, covers much of the pediment. Veneer deposits can show soil development similar to that seen in young to old alluvial fan deposits

Qpi Incised pediment (Holocene and Pleistocene)-Pediment with widely exposed bare rock cut by numerous stream channels

Qpd Deeply dissected pediment (Holocene and Pleistocene)—Remnant pediment whose surface is identified by concordant tops of pinnacles, ridges, or other bedrock remnants

\section{SUBSTRATE MATERIALS (PRE-QUATERNARY)}

ca Carbonate rocks - Carbonate mineral rocks, such as limestone, dolomite, and marble

fp Felsic plutonic rocks - Plutonic rocks with more than about $68 \% \mathrm{SiO}_{2}$, such as granite and granodiorite

fpg Felsic plutonic rocks that weather to grus

fv Felsic volcanic rocks-Volcanic rocks with more than about $68 \% \mathrm{SiO}_{2}$, such as rhyolite, dacite, rhyodacite, and felsite, including flows and ejecta

$\mathrm{mp} \quad$ Mafic plutonic rocks-Plutonic rocks with less than about $68 \% \mathrm{SiO}_{2}$, such as gabbro, diorite, monzodiorite, syenite, and alkalic rocks

$\mathrm{mr} \quad$ Metamorphic rocks-Metamorphic rocks of complexly mixed lithology, such as gneiss, migmatite, and structurally mixed rocks

$\mathrm{mv} \quad$ Mafic volcanic rocks - Volcanic rocks with less than about $68 \% \mathrm{SiO}_{2}$, such as andesite and basalt, including flows and ejecta

pc Partly consolidated deposits and rocks - Weakly to moderately consolidated sedimentary deposits, volcanic ejecta, or highly altered rocks; typically middle to late Tertiary age

SC Schistose rocks - Schist, phyllite, and other mica-rich rocks 


\section{References Cited}

Amoroso, Lee, and Miller, D.M., 2006, Surficial geologic map database of the Cuddeback Lake 30' x 60' quadrangle, San Bernardino and Kern Counties, California: U.S. Geological Survey OpenFile Report 2006-1276, 30 p., scale 1:100,000, at http://pubs.usgs.gov/of/2006/1276.

Aydin, A., and Nur, A., 1982, Evolution of pull-apart basins and their scale independence:

Tectonics, v. 1, p. 91-105.

Birkeland, P.W., 1999, Soils and geomorphology: New York, Oxford University Press, 430 p.

Birkeland, P.W., Machette, M.N., and Haller, K.M., 1991, Soils as a tool for applied Quaternary geology: Salt Lake City, Utah Geological and Mineral Survey, 63 p.

Boettinger, J.L., and Southard, R.J., 1991, Silica and carbonate sources for Aridisols on a granitic pediment, western Mojave Desert: Soil Science Society of America Journal, v. 55, p. 1057-1067.

Boettinger, J.L., and Southard, R.J., 1995, Phyllosilicate distribution and origin in Aridisols on a granitic pediment, western Mojave Desert: Soil Science Society of America Journal, v. 59, p. 1189-1198.

Bryant, W.A., 1987, Recently active traces of the Blackwater, Harper, Lockhart and related faults near Barstow, San Bernardino County, California: California Division of Mines and Geology, 17 p., 7 plates at various scales.

Burke, D.B., Hillhouse, J.W., McKee, E.H., Miller, S.T., and Morton, J.L., 1982, Cenozoic rocks of the Barstow Basin area of southern California-Stratigraphic relations, radiometric dates, and paleomagnetism: U.S. Geological Survey Bulletin 1529-E, p. 16.

Carr, M.D., Christiansen, R.L., and Poole, F.G., 1997, Bedrock geologic map of the El Paso Mountains in the Garlock and El Paso Peaks 7 1/2' quadrangles, Kern County, California: U.S. Geological Survey Miscellaneous Investigations Series Map I-2389, scale 1:24,000.

Carr, M.D., Harris, A.G., Poole, F.G., and Fleck, R.J., 1993, Stratigraphy and structure of the Paleozoic outer continental margin rocks in Pilot Knob Valley, north-central Mojave Desert, California: U.S. Geological Survey Bulletin 2015, 33 p.

Carter, B.A., 1980, Quaternary displacement on the Garlock Fault, California, in Fife, D.L., and Brown, A.R., eds., Geology and mineral wealth of the California desert: Santa Ana, CA, South Coast Geological Society, p. 457-466.

Carter, B.A., 1994, Neogene offsets and displacement rates, central Garlock Fault, California, in McGill, S.F., and Ross, T.M., eds., Geological investigations of an active margin: Boulder, CO, Geological Society of America, Cordilleran Section Guidebook, p. 345-364.

Carter, J.N., Luyendyk, B.P., and Terres, R.R., 1987, Neogene clockwise tectonic rotation of the eastern Transverse Ranges, California, suggested by paleomagnetic vectors: Geological Society of America Bulletin, v. 98, p. 199-207.

Clark, M.M., 1973, Map showing recently active breaks along the Garlock and associated faults, California: U.S. Geological Survey Miscellaneous Geologic Investigations Map I-741.

Cooke, R.U., and Mason, P.F., 1973, Desert Knolls pediment and associated landforms in the Mojave Desert, California: Revue de Geomorphologie Dynamique, v. 22, p. 49-60.

Cooke, R.U., and Warren, A., 1973, Geomorphology in deserts: Berkeley, University of California Press, $374 \mathrm{p}$.

Cox, B.F., and Diggles, M.F., 1986, Geologic map of the El Paso Mountains Wilderness study area, Kern County, California: U.S. Geological Survey Miscellaneous Field Studies Map MF1827, scale 1:24,000. 
Davis, G.A., and Burchfiel, B.C., 1973, Garlock Fault-An intracontinental transform structure: Geological Society of America Bulletin, v. 84, p. 1407-1422.

Dibblee, T.W., 1952, Geology of the Saltdale quadrangle, California: California Division of Mines, Bulletin 160, 43 p.

Dibblee, T.W., 1967, Areal geology of the western Mojave Desert, California: U.S. Geological Survey Professional Paper 522, 153 p., four plates, scale 1:125,000.

Dibblee, T.W., 1968, Geology of the Fremont Peak and Opal Mountain quadrangles, California: California Division of Mines and Geology, Bulletin 188, 64 p., four plates, scale 1:62,500.

Dibblee, T.W., 1985, Analysis of potential fault and seismic hazards to proposed Superconductor Supercollider site in vicinity of Edwards Air Force Base, western Mojave Desert, California: unpublished report for University of California at Davis, $12 \mathrm{p}$.

Dibblee, T.W., and Gay, T.E., 1952, Mineral deposits of the Saltdale quadrangle [California]: California Division of Mines, Bulletin 160, p. 45-64.

Dohrenwend, J.C., Wells, S.G., McFadden, L.D., and Turrin, B.D., 1986, Pediment dome evolution in the eastern Mojave Desert, in Gardiner, V., ed., International geomorphology, 1986Proceedings of the First International Conference on Geomorphology: London, WileyInterscience, p. 1047-1062.

Dokka, R.K., 1989, The Mojave extensional belt of southern California: Tectonics, v. 8, p. 363390.

Dokka, R.K., and Travis, C.J., 1990, Late Cenozoic strike-slip faulting in the Mojave Desert, California: Tectonics, v. 9, p. 311-340.

Eghbal, M.K., and Southard, R.J., 1993a, Micromorphological evidence of polygenesis of three Aridisols, western Mojave Desert, California: Soil Science Society of America Journal, v. 57, p. 1041-1050.

Eghbal, M.K., and Southard, R.J., 1993b, Stratigraphy and genesis of Durothids and Haplargids on dissected alluvial fans, western Mojave Desert, California: Geoderma, v. 59, p. 151-174.

Fletcher, J.M., 1994, Geodynamics of large-magnitude extension-A field-based study of the central Mojave metamorphic core complex: Salt Lake City, University of Utah, unpublished Ph.D. dissertation.

Fletcher, J.M., Bartley, J.M., Martin, M.W., Glazner, A.F., and Walker, J.D., 1995, Largemagnitude continental extension-An example from the central Mojave metamorphic core complex: Geological Society of America Bulletin, v. 107, p. 1468-1483.

Fletcher, J.M., Miller, J.S., Martin, M.W., and 3 others, 2002, Cretaceous arc tectonism in the Mojave block-Profound crustal modification that controlled subsequent tectonic regimes, in Glazner, A.F., Walker, J.D., and Bartley, J.M., eds., Geologic evolution of the Mojave Desert and southwestern Basin and Range: Geological Society of America, Memoir 195, p. 131-149.

Gale, H.S., 1946, Geology of the Kramer borate district, Kern County, California: California Journal of Mines and Geology, v. 42, p. 325-378.

Gile, L.H., Hawley, J.W., and Grossman, R.B., 1981, Soils and geomorphology in the Basin and Range area of southern New Mexico - Guidebook to the Desert Project: Socorro, NM, New Mexico Institute of Mining and Technology, $222 \mathrm{p}$.

Glazner, A.F., Walker, J.D., Bartley, J.M., and 7 others, 1994, Reconstruction of the Mojave Block, in Ross, T.M., ed., Geological investigations of an active margin, Geological Society of America Cordilleran Section Guidebook: Redlands, CA, San Bernardino County Museum Association, p. 3-30. 
Hewett, D.F., 1954a, A fault map of the Mojave Desert region [California], in Jahns, R.H., ed., Geology of southern California: California Division of Mines, Bulletin 170, p. 15-18, 1 plate. Hewett, D.F., 1954b, General geology of the Mojave Desert region, California, [part]1, in Jahns, R.H., ed., Geology of southern California: California Division of Mines, Bulletin 170, p. 5-20. Hulin, C.D., 1925, Geology and oil resources along the southern border of San Joaquin Valley, California: California Mining Bureau, Bulletin 95, p. 152.

Jennings, C.W., Burnett, J.L., and Troxel, B.W., 1962, Geologic map of California-Trona sheet: California Division of Mines and Geology, scale 1:250,000.

Keenan, D.L., 2000, The geology and geochemistry of volcanic rocks in the Lava Mountains, California: Las Vegas, University of Nevada, unpublished M.S. thesis.

Loomis, D.P., 1984, Miocene stratigraphic and tectonic evolution of the El Paso Basin, California: Chapel Hill, University of North Carolina, unpublished M.S. thesis.

Loomis, D.P., and Burbank, D.W., 1988, The stratigraphic evolution of the El Paso Basin, southern California-Implications for Miocene development of the Garlock Fault and uplift of the Sierra Nevada: Geological Society of America Bulletin, v. 100, p. 12-28.

Louie, J.N., and Qin, J., 1991, Subsurface imaging of the Garlock Fault, Cantil Valley, California: Journal of Geophysical Research, v. 96, p. 14,461-14,479.

Mabey, D.R., 1960, Gravity survey of the western Mojave Desert, California: U.S. Geological Survey Professional Paper 316-D, p. 51-73.

Machette, M.N., 1985, Calcic soils of the southwestern United States, in Weide, D.L., ed., Soils and Quaternary geology of the southwestern United States: Geological Society of America, Special Paper 203, p. 1-22.

McGill, S.F., Wells, S., Fortner, S., Kuzima, H., and McGill, J., 2009, Slip rate of the western Garlock Fault at Clark Wash, near Lone Tree Canyon, Mojave Desert, California: Geological Society of America, Bulletin, v. 121, p. 536-554.

McGill, S.F., and Rockwell, T., 1998, Ages of late Holocene earthquakes on the central Garlock Fault near El Paso Peaks, California: Journal of Geophysical Research, v. 103, p. 7265-7279.

McGill, S.F., and Sieh, K., 1991, Surficial offsets on the central and eastern Garlock Fault associated with prehistoric earthquakes: Journal of Geophysical Research, v. 96, p. 21,59721,621 .

McGill, S.F., and Sieh, K., 1993, Holocene slip rate of the central Garlock Fault in southeastern Searles Valley, California: Journal of Geophysical Research, v. 98, p. 14,217-14,231.

Michael, E.D., 1966, Large lateral displacement on Garlock Fault, California, as measured from offset fault system: Bulletin of the Geological Society of America, v. 77, p. 111-114.

Miller, D.M., and Yount, J.C., 2002, Late Cenozoic tectonic evolution of the north-central Mojave Desert inferred from fault history and physiographic evolution of the Fort Irwin area, California, in Glazner, A.F., Walker, J.D., and Bartley, J.M., eds., Geologic evolution of the Mojave Desert and southwestern Basin and Range: Geological Society of America, Memoir 195, p. 173-197.

Monastero, F.C., Sabin, A.E., and Walker, J.D., 1997, Evidence for post-early Miocene initiation movement on the Garlock Fault from offset of the Cudahy Camp Formation, east-central California: Geology, v. 25, p. 247-250.

Oberlander, T.M., 1989, Slope and pediment systems, in Thomas, D.S.G., ed., Arid zone geomorphology: London, Belhaven Press, p. 56-84.

Oskin, M., and Iriondo, A., 2004, Large-magnitude transient strain accumulation on the Blackwater Fault, eastern California shear zone: Geology, v. 32, p. 313-316. 
Pack, R.W., 1914, Reconnaissance of the Barstow-Kramer region, California: U.S. Geological Survey Bulletin 541-E, p. 141-154.

Page, P.W., and Moyle, W.R., Jr., 1960, Data on water wells in the eastern part of the middle Mojave Valley area, San Bernardino County, California: California Department of Water Resources, Bulletin No. 91-19, p. 223, 1 plate, scale 1:62,500.

Pampeyan, E.H., Holzer, T.L., and Clark, M.M., 1988, Modern ground failure in the Garlock Fault zone, Fremont Valley, California: Geological Society of America Bulletin, v. 100, p. 677-691.

Peltzer, G., Crampe, F., Hensley, S., and Rosen, P., 2001, Transient strain accumulation and fault interaction in the Eastern California Shear Zone: Geology, v. 29, p. 975-978.

Reynolds, R.E. and Fay L.P., 1989, The Coon Canyon Fault crevice local fauna-Preliminary evidence for recency of faulting in the Mud Hills, San Bernardino County, California, in Reynolds, R.E. ed., The west-central Mojave Desert-Quaternary studies between Kramer and Afton Canyon: Redlands, CA, San Bernardino County Museum Association Special Publication 89, p. 61-64.

Rowlands, P.G., 1995, Regional bioclimatology of the California Desert, in Latting, J., and Rowlands, P.G., eds., The California Desert-An introduction to natural resources and man's impact: Riverside, University of California, Riverside Press, p. 95-134.

Schell, B.A., 1994, Newly discovered faults along the northwest extension of the Lockhart Fault zone, Mojave Desert, Kern County, California, in Murbach, D., and Baldwin, J., eds., Mojave Desert: Santa Ana, CA, South Coast Geological Society, p. 239-252.

Smith, E.I., Sanchez, A., Keenan, D.L., and Monastero, F.C., 2002, Stratigraphy and geochemistry of volcanic rocks in the Lava Mountains, California-Implications for the Miocene development of the Garlock Fault, in Glazner, A.F., Walker, J.D., and Bartley, J.M., eds., Geologic evolution of the Mojave Desert and southwestern Basin and Range: Geological Society of America, Memoir 195, p. 151-160.

Smith, G.I., 1964, Geology and volcanic petrology of the Lava Mountains, San Bernardino County, California: U.S. Geological Survey Professional Paper 457, 97 p., 1 sheet, 1: 24,000.

Smith, G.I., 1991, Anomalous folds associated with the east-central part of the Garlock Fault, southeast California: Geological Society of America Bulletin, v. 103, p. 615-624.

Smith, G.I., 2009, Late Cenozoic geology and lacustrine history of Searles Valley, Inyo and San Bernardino Counties, California: U.S. Geological Survey Professional Paper 1727, 115 p.

Thompson, 1929, The Mojave Desert region, California: U.S. Geological Survey Water Supply Paper 578, $759 \mathrm{p}$.

Troxel, B.W., and Morton, P.K., 1962, Geologic map of Kern County: California Division of Mines and Geology, scale 1:250,000.

Westaway, R., 1995, Deformation around stepovers in strike-slip fault zones: Journal of Structural Geology, v. 17, p. 831-846.

Yount, J.C., Schermer, E.R., Felger, T.J., Miller, D.M., and Stephens, K.A., 1994, Preliminary geologic map of Fort Irwin Basin, north-central Mojave Desert, California: U.S. Geological Survey Open-File Report 94-173, scale 1:24,000, 27 p. 